\title{
Cordão Formation: loess deposits in the southern coastal plain of the state of Rio Grande do Sul, Brazil
}

\author{
RENATO P. LOPES ${ }^{1}$, SERGIO R. DILLENBURG ${ }^{2}$ and CESAR L. SCHULTZ \\ ${ }^{1}$ Universidade Federal do Pampa/UNIPAMPA, Campus Caçapava do Sul, Avenida Pedro \\ Anunciação, 111, Vila Batista, 96570000 Caçapava do Sul, RS, Brazil \\ ${ }^{2}$ Universidade Federal do Rio Grande do Sul/UFRGS, Instituto de Geociências, Avenida \\ Bento Gonçalves, 9500, Agronomia, 91540000 Porto Alegre, RS, Brazil
}

Manuscript received on October 19, 2015; accepted for publication on June 20, 2016

\begin{abstract}
Loess consists of silt-dominated sediments that cover $\sim 10 \%$ of the Earth's surface. In southern South America it occurs in Argentina, Bolivia, Paraguay and Uruguay, and its presence in southern Brazil was never studied in detail. Here is proposed a new lithostratigraphic unit, Cordão Formation, consisting of loess deposits in the southern Brazilian coastal plain. It consists of fine-very fine silt with subordinate sand and clay, found mostly in lowland areas between Pleistocene coastal barriers. These sediments are palecolored (10YR hue) and forms $\sim 1,5-2,0$ meter-thick stable vertical walls. The clay minerals include illite, smectite, interstratified illite/smectite and kaolinite, the coarser fraction is mostly quartz and plagioclase. Caliche and iron-manganese nodules are also present. The only fossils found so far are rodent teeth and a tooth of a camelid (Hemiauchenia paradoxa). Luminescence ages indicate that this loess was deposited in the latest Pleistocene, between $\sim 30$ and $10 \mathrm{kyrs}$ ago, and its upper portion was modified by erosion and accumulation of clay and organic matter in the Holocene. The estimated accumulation rate was $\sim 630 \mathrm{~g} /$ $\mathrm{m}^{2} /$ year. The probable source of this loess is the Pampean Aeolian System of Argentina and it would have been deposited by the increased aeolian processes of the last glacial.
\end{abstract}

Key words: Chuy Creek, coastal plain, Last glacial stage, Loess, Pleistocene.

\section{INTRODUCTION}

Loess is a type of sediment dominated by silt-sized particles $(0,004-0,062 \mathrm{~mm}$ in the scale of Wentworth 1922), transported and accumulated by aeolian activity (Pye 1984, Muhs 2006). The loess found in the Northern Hemisphere consists chiefly of quartz (up to $60-70 \%$ ), carbonate (20 to $30 \%$ ), clay minerals (10 to $20 \%$ ) and variable amounts

Correspondence to: Renato Pereira Lopes

E-mail: paleonto_furg@yahoo.com.br of feldspars, heavy minerals, and volcanic glass (Smalley 1966, Pye 1984). Loessic sediments usually form massive deposits, but are often found intercalated with paleosoils; the grains are weakly cemented by iron oxide or carbonate, but form vertical, stable walls under dry conditions (Pécsi 1990). This material is divided in primary (of aeolian origin) and secondary (primary loess that was re-worked and re-deposited by other mechanisms).

The formation of loessic deposits encompasses an initial phase of weathering, followed by 
transportation and deposition in floodplains, glacial outwashes or peridesertic areas by ice and rivers, and finally, aeolian deflation and accumulation, which requires a trapping mechanism, such as topographic features or vegetation (Pye 1995, Wright 2001, Iriondo and Kröhling 2007a). Although most loess deposits are found close to glaciated areas, formed by particles that were generated by frost weathering and mechanical grinding by glaciers, other deposits occur close to deserts, where processes such as insolation and salt weathering form silt-sized particles (Tsoar and Pye 1987, Iriondo 1999a, Wright 2001).

Extensive loess deposits cover some 10\% of the global land surface area and are found in Central Asia, Africa, Europe, New Zealand, North and South America. The largest and most important loess deposits of South America are found in Argentina (the 'Pampean Formation'), covering an area of some $300.000 \mathrm{~km}^{2}$ between $23^{\circ}$ and $38^{\circ} \mathrm{S}$ (d'Orbigny 1842, Darwin 1846, Teruggi 1957, Zárate and Blasi 1991, 1993). Smaller deposits are found in Uruguay and in the Chaco area of Bolivia and Paraguay (Iriondo 1997, Muhs 2006, Latrubesse et al. 2012). In Uruguay, loessic deposits are associated to the Pleistocene Libertad I, II and Dolores-Sopas formations (Panario and Gutiérrez 1999, Veroslavsky et al. 2004).

The loess deposits of Argentina form a 2.000 $\mathrm{km}$-long and $300 \mathrm{~km}$-wide belt surrounding the Pampean Sand Sea (Iriondo and Kröhling 2007a). Despite of the similar grain size (silt and sandy silt) as the North American and European loess, the high proportion of plagioclase over quartz and the abundance of volcanic glass shards indicates a volcano-pyroclastic origin for the Argentinean loess (Teruggi 1957). The loess found to the south of $30^{\circ} \mathrm{S}$, is predominantly composed of sandy silt, derived from rocks of the Patagonian Andes and redistributed by southern winds. The loess found between $23^{\circ}$ and $30^{\circ} \mathrm{S}$, called Neotropical loess by Sayago (1995), is mainly silty clay and consists of material generated in the Bolivian Andes and accumulated in lowlands of Bolivia, Paraguay and northern Argentina by northern winds (Sayago 1995, Iriondo 1997, Zárate 2003). The decrease of coarse-grained material reflects the increasing distance from the source area (Zárate and Blasi 1991, Sayago 1995).

Although some authors (Delaney 1962, Soliani, 1973, Bombin 1976, Gomes et al. 1987, Zárate 2006) have mentioned the presence of loess in southern Brazil, represented by silty, calichebearing sedimentary deposits, its occurrence was not subject to detailed studies so far. Here is proposed a formal lithostratigraphic unit that encompasses the loess deposits found in the southern coastal plain of the state of Rio Grande do Sul (CPRS), based on descriptions of its characteristics, distribution, mineralogical composition and age, and proposing a possible origin and mechanisms of deposition.

\section{GEOLOGICAL BACKGROUND}

The CPRS is the emerged uppermost portion of the Pelotas Basin, a marginal sedimentary basin developed after the split between South America and Africa in the Cretaceous (Villwock and Tomazelli 1995). Lithostratigraphically, the Cenozoic sediments of the CPRS constituted the Patos Group, divided into Graxaim (alluvial deposits), Chuy (shallow marine deposits) and Itapoã (aeolian deposits) Formations (Delaney 1965). This same author designed as 'Caliche Cordão' the carbonatic horizon found within the silty sediments in southern CPRS, presumably representing a pedogenic modification of the Chuy Formation. Later, the fossil-bearing fluvial facies overlying that unit was designed Santa Vitória Formation (Soliani 1973). The siltyrich, caliche-bearing layer above the Santa Vitória Formation was designed 'Cordão Soil Unit' and regarded as the product of pedogenetic modification of the the former (Jost 1975).

During the 1980s, the geology of the CPRS was reviewed and a new scheme, based upon 
the recognition of chronostratigraphic units encompassing facies associations, was adopted for describing the large-scale geological structure of the plain (Villwock and Tomazelli 1995, Tomazelli and Villwock 2005). Under this new scheme, the CPRS encompasses two large sets of depositional systems: the Neogene Alluvial Fans (corresponding to the Graxaim Fm.) and the Quaternary BarrierLagoon systems (Villwock and Tomazelli 1995, Tomazelli et al. 2000). The latter consist of four systems formed by successive sea-level highstands linked to glacioeustatic oscillations in the last $\sim 400$ $\mathrm{ka}$, which reworked the uppermost terrigenous clastic sediments of the Pelotas Basin (Rosa 2012, Dillenburg and Barboza 2014).

Although Delaney (1965) grouped all marine deposits of the CPRS as Chuy Formation, it has been recognized that the barrier-lagoon systems are chronostatigraphically distinct units (Villwock and Tomazelli 1995). The Barrier II would have been formed by the sea-level highstand that reached its maximum around $220 \mathrm{kyrs}$ ago, correlated to the marine isotope stage (MIS) 7e, according to electron spin resonance (ESR) datings on fossil shells and luminescence ages from sediments of the marine facies (Lopes et al. 2013, 2014). The Barrier III was formed by the sea-level highstand of $\sim 125$ kyrs ago (MIS 5, Tomazelli and Dillenburg 2007, Lopes et al. 2015), whereas the Holocene barrier (IV) comprises the present-day coastline, developed in the last 10 kyrs (Caron 2007, 2014, Lima et al. 2013). This barrier has the same siliciclastic composition as the Pleistocene ones, but with smaller amounts of clays or feldspars (Villwock and Tomazelli 1995).

The barrier systems encompass marine and aeolian facies, in an environmental sense (Reading 1986), i.e., according to the different depositional environments that characterize these systems. The marine facies of the Pleistocene barriers are exposed only in man-made excavations, gullies and river banks, and consist of fine, well-sorted medium to fine quartz sand, with some amounts of heavy minerals and biogenic carbonates. The aeolian facies consist of fine, well-sorted quartz sand with subordinate feldspars, iron oxide nodules, heavy minerals, mica and small amounts of clays and organic matter, related to postdepositional pedogenesis (Villwock and Tomazelli 1995).

In the southern CPRS the barrier-lagoon systems II, III and IV are well-represented by long sandy barriers stretching for more than $200 \mathrm{~km}$, parallel to each other and intercalated with the lagoon systems (Figure 1). The lagoon systems II and IV include two large coastal lakes (Mirim and Mangueira, respectively), while the Lagoon System III is a large lowland plain between the barriers II and III, mostly covered by soils, wetlands and small streams. The largest stream found in this plain is the Chuy Creek, renown for the presence of Pleistocene mammals in deposits exposed along its banks (Paula Couto and Cunha 1965, Lopes et al. 2009, Pereira et al. 2012, Lopes 2013). In the study area, the creek was very shallow $(<1$ meter) until the early 1960s, when it was dredged and further deepened for agriculture purposes, thus exposing the stratigraphic sequence described here.

Present-day climate in the study area is warm temperate-warm subtropical, with predominant winds from SW (autumn-winter) and NE (springsummer); annual rainfall ranges from 1.000 to $1.500 \mathrm{~mm}$, occasionally increasing due to influence of the El Niño (ENSO) phenomenon (Dillenburg and Barboza 2014). The southern CPRS is part of the Pampa landscape that stretches between the central-southern Rio Grande do Sul and northeastern Argentina (Roesch et al. 2009).

\section{MATERIALS AND METHODS}

The recognition of the silty sediments found in the southern CPRS as having a distinct origin from the neighboring units is a result of an ongoing research program focused on the evolution of the southern CPRS from the middle Pleistocene to the 


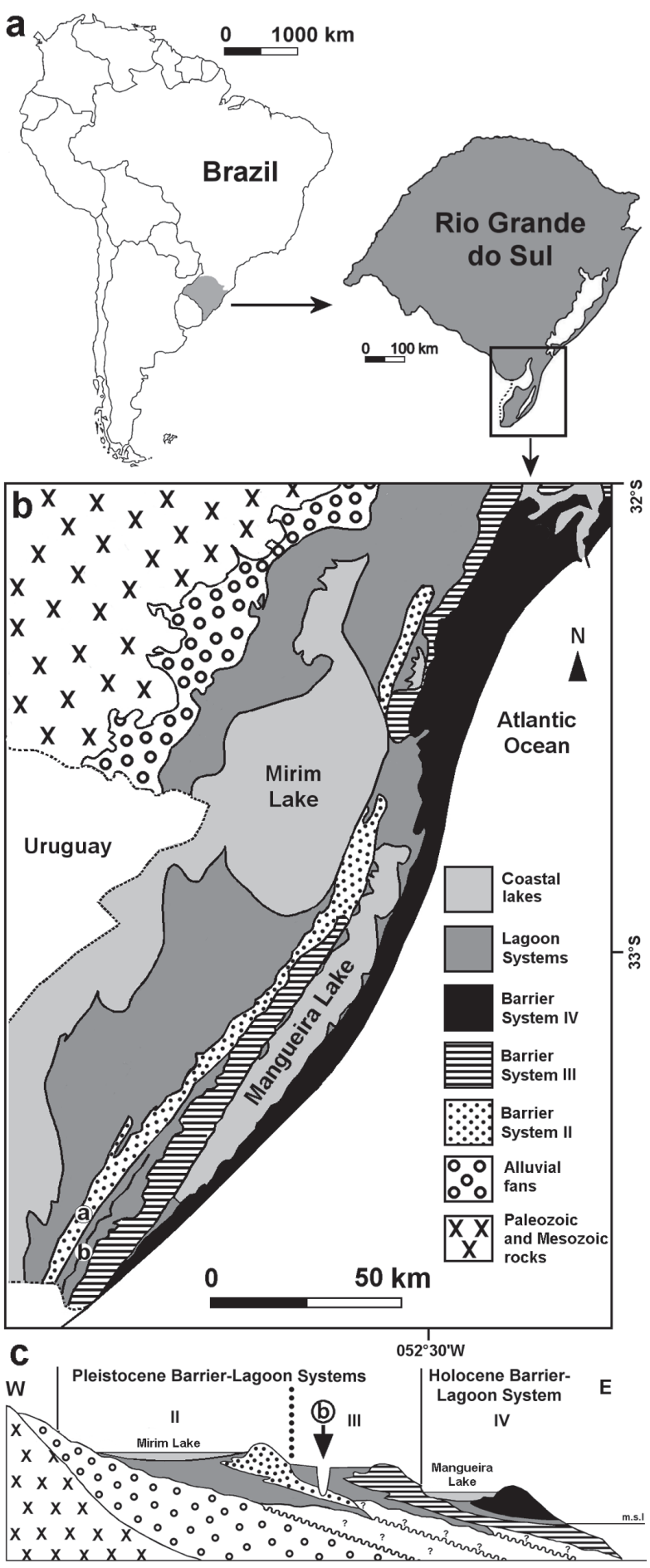

Figure 1 - a: location of the study area. b: geological structure of the southern CPRS. c: west-east transect of the depositional systems in the southern coastal plain (Modified from Villwock and Tomazelli 1995, Tomazelli and Villwock 2005, Rosa 2012). Localities mentioned in the text are Santa Vitória do Palmar (a) and Chuy Creek (b).
Holocene, using geological and fossil proxies. This research is based on field descriptions of outcrops, sedimentological analyses and fossil collecting in the Barrier-Lagoon Systems II, III and IV.

Because most of the geomorphological units are covered by vegetation, crops and wetlands, fieldwork has been performed in places where natural or man-made exposures of the stratigraphic units are found. The best outcrops are found along the banks of Chuy Creek, lake margins, gullies, and irrigation channels excavated in the barriers II and III. In each outcrop stratigraphic profiles were described after the removal of up to $10-20$ centimeters of the weathered surface sediments. The description of color followed the Munsell soil color scale. Sediment samples were collected at the lower, middle and upper parts of each barrier for grain-size comparisons.

At the outcrops along the creek, sediment samples were collected at 10 centimeter intervals to evaluate grain-size variations related to facies changes. Values of magnetic susceptibility (MS) were measured in situ from different outcrops in vertical profiles at 5 centimeter intervals using a KT-9 portable kappameter. The MS values are related to the presence of ferromagnetic minerals, and allow distinguishing between loess and paleosoils (Maher 1998). From the outcrop chosen to be the type section, on the left bank of Chuy Creek, two blocks of loess weighing $\sim 2 \mathrm{~kg}$ each (samples Lo-01 and Lo-02) were collected for age determination by optically stimulated luminescence (OSL), using the single-aliquot regenerative (SAR) protocol. The sample Lo-1 was collected some 80 centimeters above the boundary with the underlying Santa Vitória Formation, and Lo-2 was collected $\sim 80$ centimeters above. One articulated freshwater bivalve was collected from the uppermost layer in the right bank for radiocarbon dating at Beta Analytic Inc (sample Beta 384083).

Granulometric and morphoscopic analyses followed the method of Folk (1980). The 
sediment samples, weighing about $50 \mathrm{~g}$ each, were dried, disaggregated with mortar and pestle, homogeneized and then sieved through $1 / 2$ phi mesh sieves. Additional analyses were performed using a Horiba L-950 V2 laser scattering particles size, in order to establish the relative proportions of size classes of the fine $(<0.062 \mathrm{~mm})$ fraction.

Five samples weighing up to $10 \mathrm{~g}$ each, consisting of the fine fraction of the loess were selected for qualitative X-ray diffractometry (XRD) analyses at the Laboratório de Mineralogia of Universidade Federal do Rio Grande do Sul (UFRGS), to identify the clay mineral content. Ten samples from the aeolian facies of the barriers II and III were also analysed to compare the mineralogical compositions. The samples were dried and crushed for total analysis, and the fractions $<0.004 \mathrm{~mm}$ were mounted in glass slides for natural, glycolated and calcined analyses. The samples were read in an automated Siemens-Bruker AXS D5000 diffractometer $(\mathrm{Cu}-\mathrm{K} \alpha$ radiation, $40 \mathrm{kV}, 25 \mathrm{~mA})$.

One nodule $(<1 \mathrm{~cm}$ in diameter) found in the loess was cut in half and subject to energydispersive X-ray spectroscopic (EDS) analysis in order to determine its composition, using a Jeol JSM-6610LV electron scanning microscope (MEV) at the Centro de Microscopia Eletrônica do Sul (CEME-Sul) of the Universidade Federal do Rio Grande (FURG).

\section{RESULTS}

\section{HIERARCHY AND NAME}

Although the traditional lithostratigraphic subdivision of the CPRS was replaced by the concept of depositional systems (Villwock and Tomazelli 1995), the proposal of a new lithostratigraphuic unit presented here is based on the recognition that its origin is distinct from the barrier-lagoon systems. This new lithostratigraphic unit is recognized according to the criteria established by the Brazilian stratigraphic code (Petri et al. 1986). It is classi- fied as a formation based on its lithologic uniformity, distinctive lithology from adjacent units, lateral continuity and mapeability in the 1:25.000 scale. Besides, its fossil content seems distinct from those of the adjacent units.

The name Cordão was taken from the locality where Delaney (1965) described caliche deposits of the southern CPRS. Later, this name was adopted for designating the caliche-bearing silty sediments, then classified as a soil unit (Jost 1975), now recognized as the Cordão Formation.

\section{STRATOTYPE AND DISTRIBUTION}

The best outcrops of this unit are exposed along the banks of Chuy Creek. The designed stratotype (Figure 2) is located on the left bank, some $6 \mathrm{~km}$ to the SE of the town of Santa Vitória do Palmar, at the UTM coordinates 6282334S / 0283287E. Here, the bank rises about $\sim 56$ meters above the creek bed (Figure 2). The lowermost two meters belong to the marine facies of the Barrier System II (Rosa 2012, Lopes et al. 2013), and consist of fine, wellsorted quartz sand with heavy minerals, cross and parallel stratifications, fossil molluscan shells and ichnofossils Ophiomorpha nodosa and Rosselia sp. (Lopes et al. 2014).

At the stratotype section, two overlapped fluvial deposits ( $\mathrm{f} 1$ and $\mathrm{f} 2$ in Figure 2), measuring $\sim 1$ meter in total thickness, mark the transition from the marine facies to the Santa Vitória Formation above. The latter encompasses paleosoils and lensshaped fluvial deposits that measure up to 10 meters in length, up to 40 centimeters in thickness, and contain a diverse fossil assemblage of Pleistocene mammals (Lopes 2013). The sediment is mostly fine sand, with up to $20-25 \%$ of silt and clay. The boundary between the marine facies of the Barrier II and the fluvial deposits of the Santa Vitória Formation is erosive, but in places where the latters are absent, the marine sediments grade to paleosoils and aeolian deposits. 


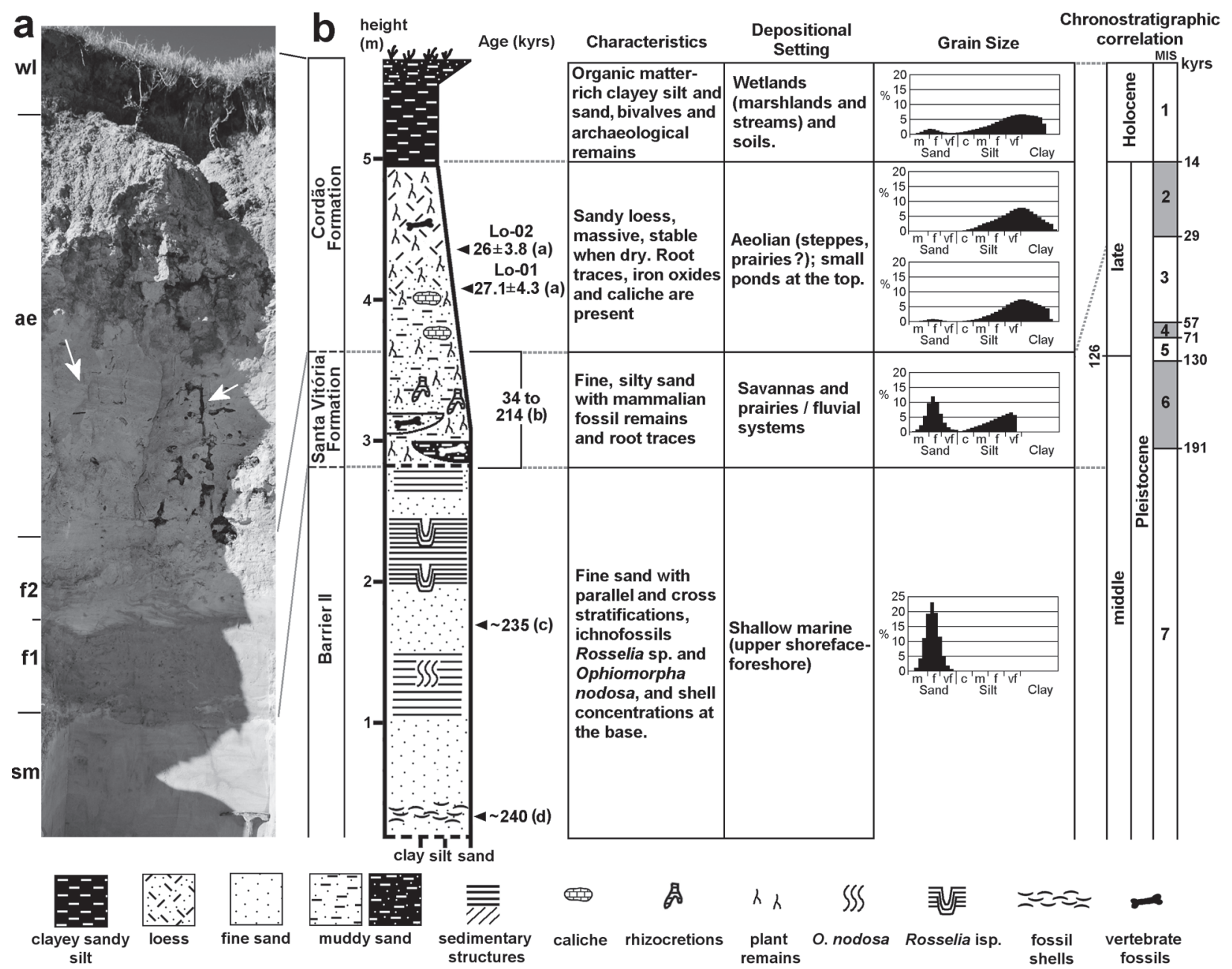

Figure 2 - a: Stratotype section of the Cordão Formation showing the succession of depositional environments (sm $=$ shallow marine, $\mathrm{fl}$ and $\mathrm{f} 2$ = fluvial, ae = aeolian, $\mathrm{wl}=$ wetlands), the right arrow indicates subhorizontal laminations, and the left one show root traces. b: Stratigraphy, description of the main characteristics and interpretation of the facies succession exposed on the banks of Chuy Creek. The chronostratigraphic correlation is based on: (a) OSL ages (this paper), (b, d) ESR ages from Lopes et al. (2010, 2013) and (c) TL ages from Lopes et al. (2014).

The Cordão Formation conformably overlies the Santa Vitória Formation. The transition is marked by a gradual increase in silt-sized particles, which form a layer with thickness between $\sim 1,5$ and 2 meters; at the stratotype section, it is nearly 2 meter-thick. The loess deposits are better preserved in the lowlands of the Lagoon System III, located between the barriers II and III. In the surrounding terrain the loess is mostly covered by wetlands and modern vegetation, but is visible in gullies and channels cut into the sediments (Figure 3a). Along the banks of Chuy Creek, the loess deposit is continuously exposed for some 20 kilometers (Figure 3b).

Sediment samples collected from several boreholes made in the vicinity of Chuy Creek show the presence of silty sediments in the uppermost aeolian facies of the Barrier III (Figure 4), but its distribution is not homogeneous and it is covered by clayey silt and wind-blown sand from the Barrier III. The presence of a silt-rich layer, probably of loessic origin, was reported by Gomes et al. (1987) from an outcrop of the Barrier III exposed on the coastline. Although a distinct loess layer was not 


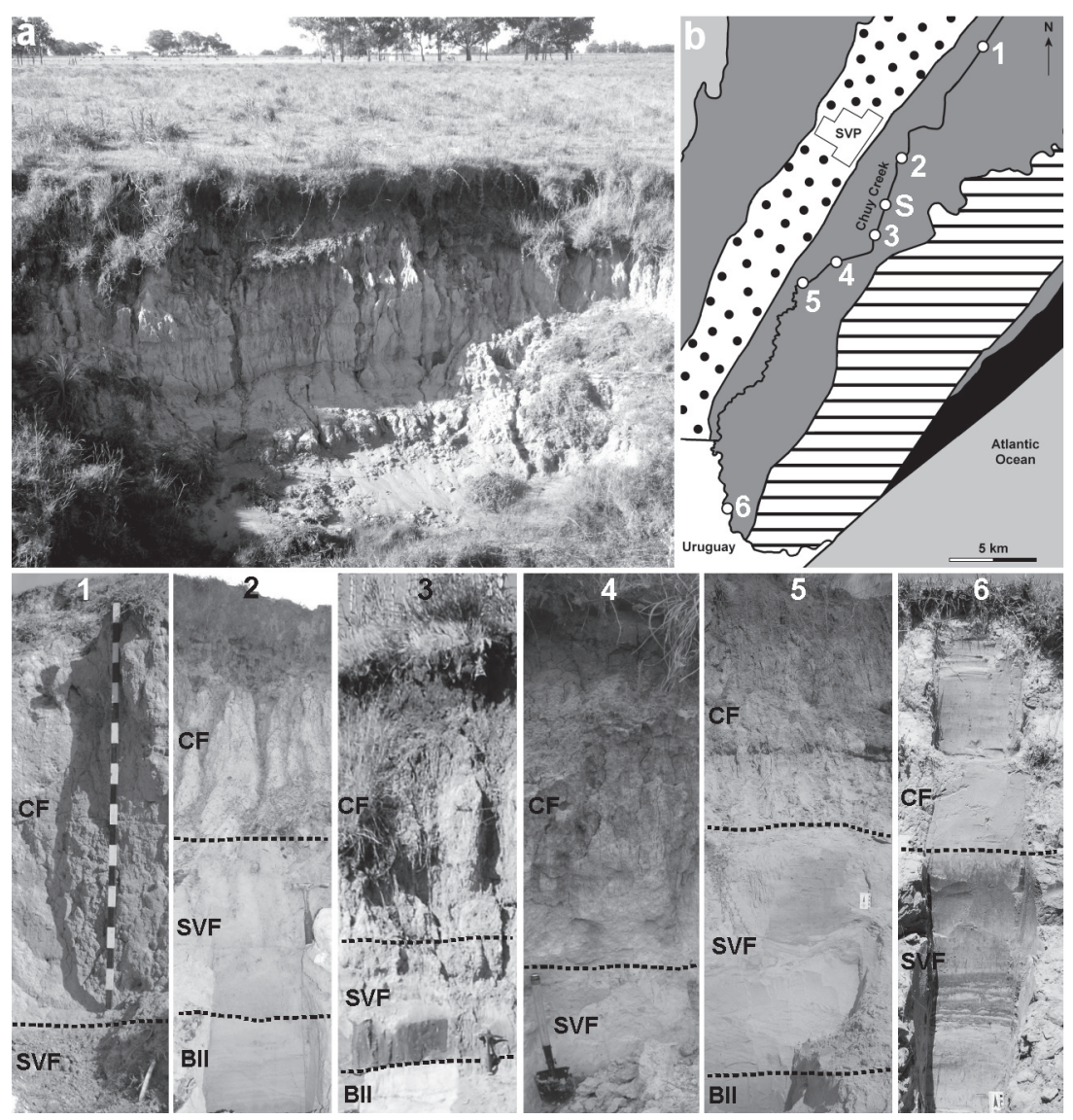

Figure 3 - a: The Cordão Formation exposed in a gully. b: Detail of the southernmost CPRS near the town of Santa Vitória do Palmar (SVP) with the location of the stratigraphic sections (1-6) below, exposed along Chuy Creek (SVP = Santa Vitória do Palmar, $\mathrm{S}=$ stratotype section shown in Figure 2, BII = Barrier II, SVF = Santa Vitória Formation, $\mathrm{CF}=$ Cordão Formation).

observed in the Barrier II, Gomes et al. (1987) described the existence of small deflation basins filled with silt on top of this barrier.

\section{PHYSICAL PROPERTIES}

The physical differences observed in the loess deposits allowed to distinguish a lower and an upper layer. The lower layer of the Cordão Formation is thicker ( $>1$ meter), and exhibits the characteristic features of loess deposits. It is consolidated and forms vertical, stable walls (Figure 5a) that are more resistant to erosion than the underlying sandy fluvial and marine sediments (Figure 5b), but become friable when saturated with water. Prismatic structures are formed due to the presence of clay and its color varies from very pale brown (10YR 8/2) to pale yellow (5YR 8/2).

This layer is usually homogeneous and massive, without erosive surfaces within it, but subhorizontal laminations were observed in the stratotype section (see Figure 2). Distinct, well-developed paleosoil horizons are not present, but plant root traces are common and sparsely distributed. These traces occur in the form of vertical and horizontal fissures filled by organic matter-rich clay that can reach several centimeters in depth (Figure 5c). Several root traces are surrounded by halos or crusts of iron and manganese (Figure 5d). Centimetric, subspherical dark reddish to dark brown ironmanganese nodules are present but sparsely 


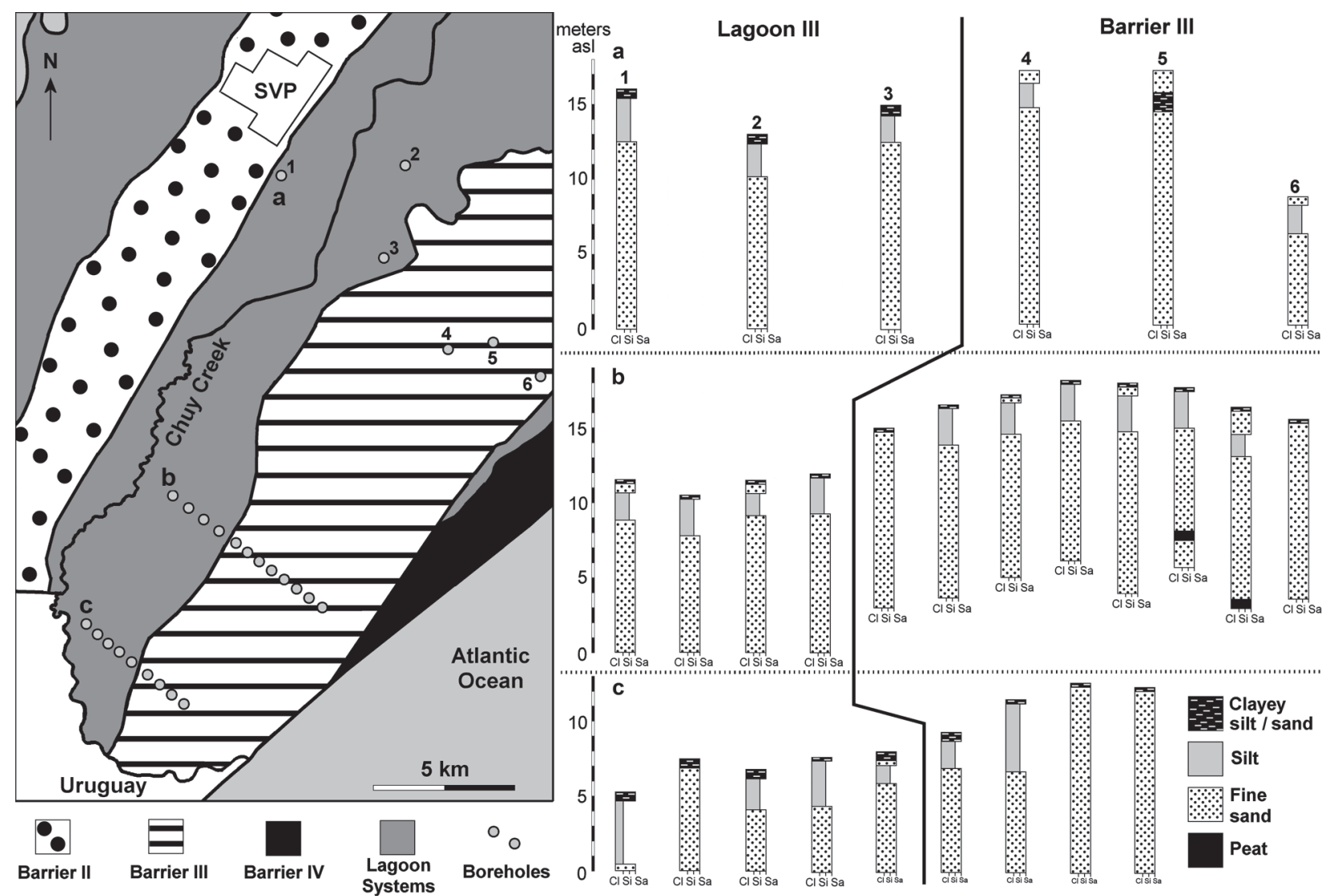

Figure 4 - Geological map of the southernmost CPRS near the town of Santa Vitória do Palmar (SVP) showing the NW-SE transects (a, b and $\mathbf{c})$ along which the boreholes shown on the right were drilled.

distributed, found either isolated or in horizontal groupings (Figure 5e). At some outcrops, the loess is mottled by iron oxide.

The MS values taken in situ from the loess exposed along the banks of Chuy Creek ranged from 0,10 to $0,28 \times 10^{-3} \mathrm{SI}$ units (Table I). These are higher than those from waterlogged sediments of the upper layer, but lower than the values found in modern well-drained soils developed on top of Barriers II and III. Despite small differences between each profile, the MS values found in the lower layer tend to increase upwards. The highest values $\left(>0,20 \times 10^{-3} \mathrm{SI}\right.$ units) were found where iron oxide nodules and mottling are present.

Caliche nodules and concretions (Figure 5f) occur in the lower half of the formation. In the Santa Vitória Formation below, the caliche consist of rhizocretions (sensu Klappa 1980), formed by carbonate precipitation around plant roots, rather than nodules. The caliche deposits found in the southern CPRS constitute the "Caliche Cordão" described by Delaney (1965). Although its distribution throughout the region is patchy, a $\sim 460$ meter-long continuous horizon is observed along the banks of the creek (Lopes et al. 2016a).

The granulometric analyses show a predominance of well-sorted sand in the subaerial portion of the Pleistocene barriers, with modal class in the fine $(0,125-0,25 \mathrm{~mm})$ fraction. In both barriers the total amount of fine sediments $(<0,062 \mathrm{~mm})$ does not exceed $4 \%$, and these are mostly clays of pedogenic origin concentrated in the B horizon (Villwock and Tomazelli 1995, Stevaux and Dillenburg 2011). The loess, on the other hand, consists mostly of fine to very fine silt, with the highest amount of sand found in its lower half and decreas- 
ing upwards. Up to $20 \%$ of the sediments from the Santa Vitória Formation consist of silt and clay, but in the Cordão Formation the silt content surpasses $40 \%$ at some outcrops. The average relative proportion between clay $(6 \%)$, silt $(72 \%)$ and sand
$(22 \%)$ of the analyzed samples indicates that texturally the loess is a silt loam, according to the US Soil Survey Staff classification (1993). The amount of fine and very fine sand ( $>20 \%)$ allows to classify it as sandy loess, sensu Pye (1984).


Figure 5 - a: vertical walls formed by loess on the right bank of Chuy Creek. b: cavities at the base of the loess, caused by erosion of the less cohesive underlying muddy sand. c: plant root remains. d: iron-manganese crust formed around a plant root. e: concentration of iron-manganese nodules. $\mathbf{f}$ : caliche nodules at the base of the Cordão Formation (CF) and rhizocretions below, in the Santa Vitória Formation (SVF). (BII = Barrier II). 
TABLE I

Magnetic susceptibility values from the loess and the Barrier III in the southern CPRS

MS values (x 10 $\left.{ }^{-3} \mathrm{SI}\right)$.

\begin{tabular}{cccc}
\multicolumn{4}{c}{ MS values (x 10 } \\
\hline & Lower Cordão Fm. & Upper Cordão Fm. & Barrier III \\
\hline Min. & 0,10 & 0,10 & 0,26 \\
Max. & 0,28 & 0,18 & 0,49 \\
Mean & 0,17 & 0,13 & 0,34 \\
\hline
\end{tabular}

Morphoscopic analyses show that the sandy fraction of the loess is a mixture of well-rounded, polished and subangular frosted grains, varying in shape from subspherical to elongated. This fraction consists of quartz and plagioclase, with some amounts ( $\sim 10-20 \%)$ of other minerals such as mica, and epidote. Although common in loess deposits, volcanic glass was very scarce in the analyzed samples. The mineralogical similarity between the loess and the Barrier III suggests some contribution from the latter, probably by aeolian deflation.

The qualitative $\mathrm{X}$-ray diffraction analysis showed few differences in mineral composition between the loess and the Pleistocene barriers (Table II, Figure 6a, b). All units contain essentially quartz and plagioclase, and micas were detected in the loess and in the Barrier III. K-feldspar, although present in both barriers, was not detected in the loess samples. Regarding the clay mineral fraction, illite and illite/mica are present on all samples, and

TABLE II

Distribution of the minerals identified by X-ray diffraction in the coarse and clay fractions of the Barriers II and III and in the loess of the Cordão Formation.

\begin{tabular}{cccc}
\hline Minerals & B II & B III & Loess \\
\hline Quartz & $\mathrm{X}$ & $\mathrm{X}$ & $\mathrm{X}$ \\
Plagioclase & $\mathrm{X}$ & $\mathrm{X}$ & $\mathrm{X}$ \\
K-feldspar & $\mathrm{X}$ & $\mathrm{X}$ & \\
Mica & & $\mathrm{X}$ & $\mathrm{X}$ \\
\hline Clays & & & \\
\hline Kaolinite & & $\mathrm{X}$ & $\mathrm{X}$ \\
Illite & $\mathrm{X}$ & $\mathrm{X}$ & $\mathrm{X}$ \\
Illite/Smectite & & & $\mathrm{X}$ \\
Smectite & & & $\mathrm{X}$ \\
Illite/Mica & $\mathrm{X}$ & $\mathrm{X}$ & $\mathrm{X}$ \\
\hline
\end{tabular}

kaolinite was detected only in the Barrier III and in the loess. Smectite and interstratified illite/smectite (I/S) were present only in the loess (Figure 6b). The EDS analysis of a nodule from the loess revealed the presence of quartz, iron and manganese, plus
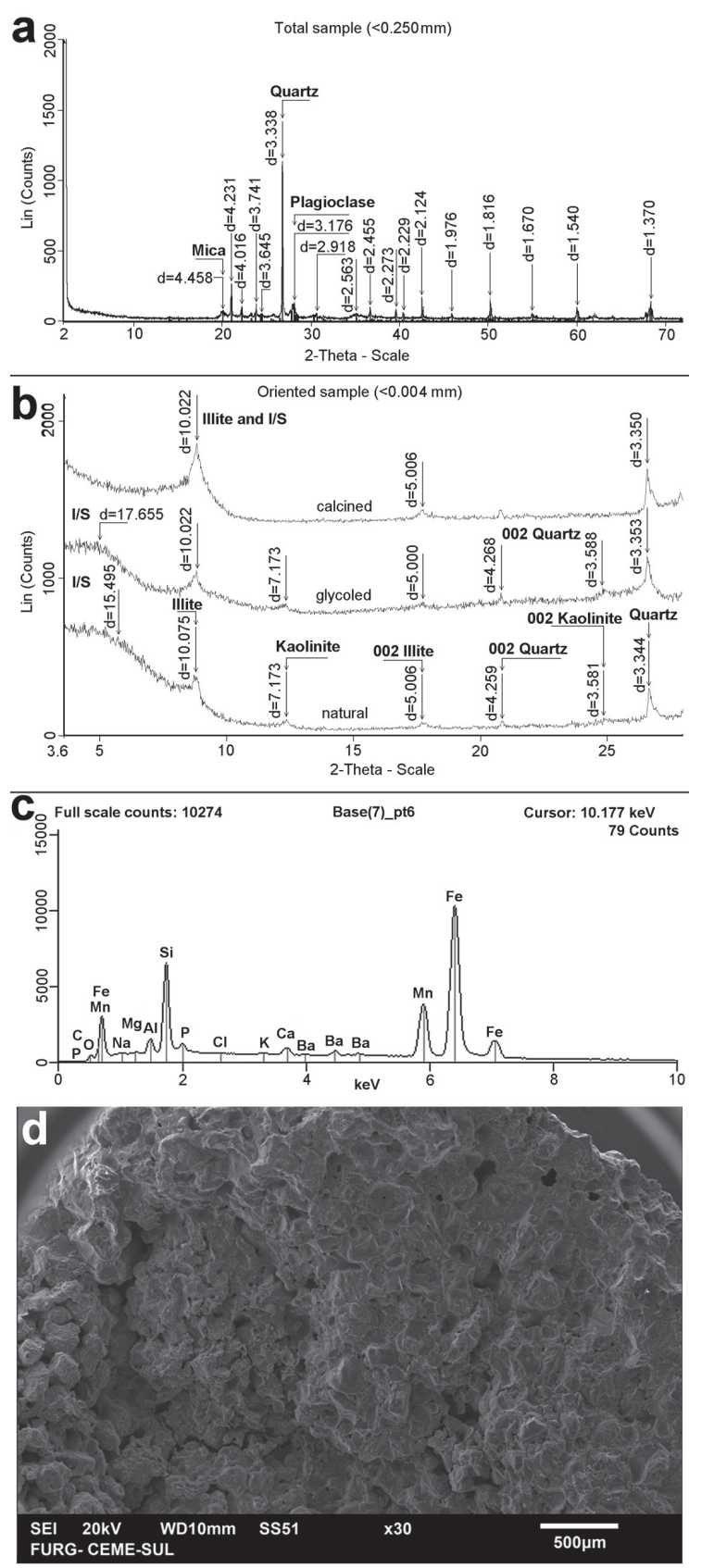

Figure 6 - Diffractograms showing the mineral composition of the total (a) and clay (b) fractions of the loess. (c) is the mineral composition and (d) is a MEV image of an ironmanganese nodule from the loess. 
other elements (Figure 6c), and the MEV image (Figure 6d) shows that the nodules consist of sediment grains cemented together, probably by the iron manganese oxides dissolved and precipitated from vadose waters.

The boundary between the lower and upper layers of the formation is sharp and bioturbated by roots. The upper layer is a $0,5-1,0$ meterthick layer of clayey silt and sand characterized by the increase in the amount plant-derived organic matter, which produces the dark brown color $(7.5 \mathrm{R}$ $3 / 2$ ). These features indicate that the upper loess layer was modified by pedogenesis, plant growth and sediment reworking in wetland environments (fluvial, lacustrine, swamps), under wetter (and probably warmer) climate. It is mostly massive, but at some points along the banks it is laminated, and at one outcrop is interbedded with a layer of diatomite (Figure 7a). In two other outcrops along the banks, lens-shaped bodies of laminated diatomite are interbedded between the lower and upper formation (Figure 7b). In another outcrop, the top of the lower formation is truncated by an erosive surface, and the sediments deposited on top of it are laminated and contain freshwater bivalves and fragmented bones (Figure 7c), thus indicating that the original upper loess was eroded and reworked by a fluvial system.

The sand present in soil formed in at the top of the sequence is probably material reworked from the uppermost Barrier III, which until recent years was subject to aeolian deflation but now is
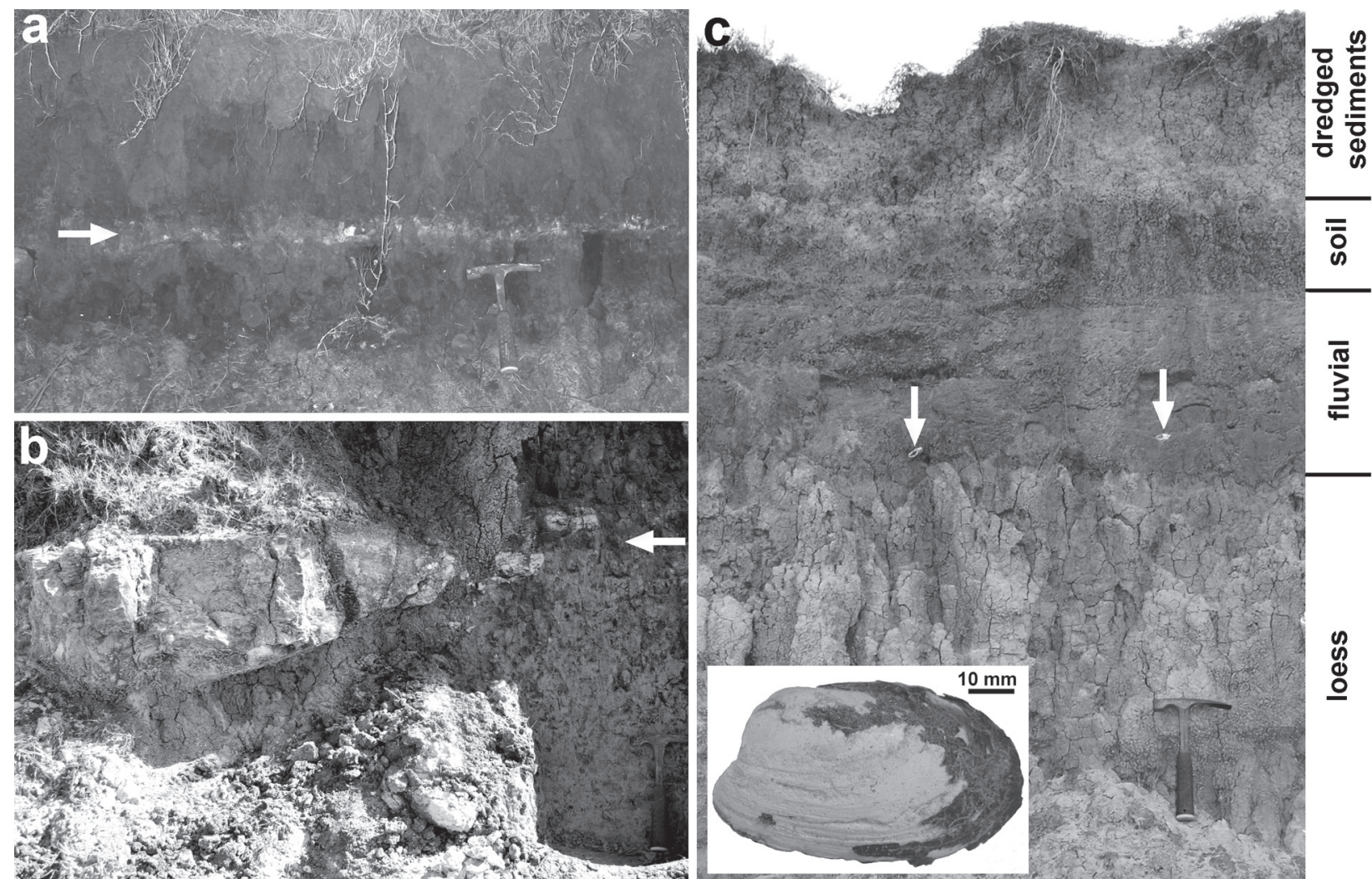

Figure 7 - a: Diatomite layer (the light-colored streak pointed by the arrow) within the upper Cordão Formation. b: Diatomite body (the lenticular white structure on the left of the photo) outcropping on the right bank, at the boundary (pointed by the arrow) between the lower and upper Cordão Formation. c: Detail of the right bank of Chuy Creek, showing the erosive boundary between the Pleistocene loess below and a Holocene fluvial system. The arrows indicate a fragmented bone (on the left) and one articulated bivalve Diplodon (on the right, also shown on the insert). 
stabilized by plant growth (Lopes et al. 2015). Holocene archaeological remains are common at or close to the surface (Schmitz et al. 1997).

\section{FOSSIL CONTENT}

Until recently, plant root traces were the only remains of organic origin found in the Cordão Formation. Pollen remains were not preserved, therefore it is not clear yet what kind of vegetation was present at the time of loess deposition. Systematic collecting through the last ten years revealed scarce vertebrate fossils, in the form of poorly preserved, unidentifiable small fragments. The only identifiable vertebrate fossils so far are fragments of rodent incisors and one fragment of a camelid maxila (Figure 8). Both are part of the paleontological collection of the Tancredo Fernandes de Mello museum (MCTFM), in the town of Santa Vitória do Palmar, and were found close to each other, above the carbonate nodules.

The camelid maxilla (MCTFM-PV1028, Figure 8a) was found in the upper part of the lower formation on the left bank of Chuy Creek, about 1 $\mathrm{km}$ to the north of the stratotype section (see Figure 2 ). The specimen has one molar still inserted on the alveolus, and the morphology indicates that it is an upper second molar (m2) of Hemiauchenia paradoxa (C.S. Scherer, pers. comm.), the only recognized species of this genus found in southern Brazil (Scherer et al. 2007). The tooth is complete and well-preserved, with few cracks on its surface, but the bone of the maxilla is highly weathered, with longitudinal cracking throughout its surface, which indicates long time of exposure to the elements prior to the final burial (Behrensmeyer 1978).

The rodent incisors (MCTFM-PV1030, Figure $8 b)$ are very incomplete, and their morphology or measurements do not allow a more precise taxonomic assignment. Another fossil that probably was preserved within the loess is a right dentary of a rodent of the genus Lagostomus (chinchilla or vizcacha), described by Kerber et al. (2011). This specimen, however, was found among eroded sediments just below the base of the loess layer, therefore its precise stratigraphic setting is not known.

AGE

The loess samples provided ages of $27.100 \pm$ $4.300 \mathrm{yrs}(\mathrm{Lo}-01)$, and $26.000 \pm 3.800 \mathrm{yrs}$ (Lo02, Table III). These results are consistent with thermoluminescence (TL) ages from sediments and electron spin resonance (ESR) ages of fossil teeth from the underlying Santa Vitória Formation, with ages ranging from $\sim 214$ to 34 kyrs (Lopes et al. 2010, 2013, 2014).

The upper layer of the Cordão Formation is probably chronocorrelated to a $\sim 1$ meter-thick organic matter-rich clayey silt found on top of Pleistocene sediments a few kilometers to the southeast of Chuy Creek, which provided an age of $9.855 \pm 305$ cal yrs BP (Lima et al. 2013). Caron (2014) also found similar material in a
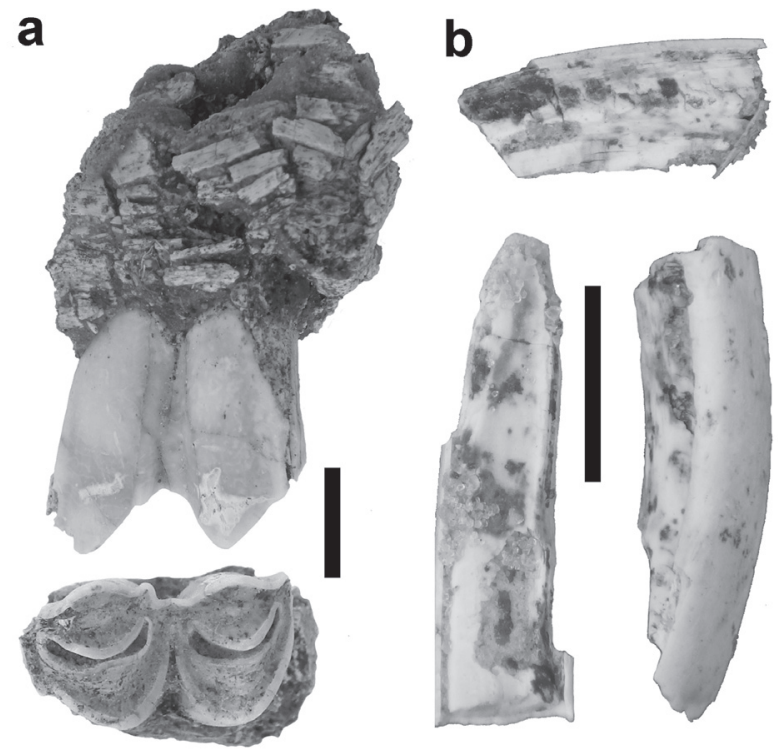

Figure 8 - Fossils from the Cordão Formation. a: upper m2 of Hemiauchenia paradoxa (MCTFM-PV1028) in labial and occlusal views. b: fragmented incisors of rodents (MCTFMPV1030). Scale bars $=10 \mathrm{~mm}$. 
TABLE III

OSL ages of the Cordão Formation.

\begin{tabular}{ccccc}
\hline Sample no. & Annual dose $(\boldsymbol{\mu G y} /$ year) & Mean paleo-dose $(\mathbf{G y})$ & SD $(\boldsymbol{\sigma})$ & Age $($ years) \\
\hline Lo-02 & $2.290 \pm 230$ & 59,6 & 3,5 & $26.000 \pm 3.880$ \\
Lo-01 & $2.080 \pm 230$ & 56,3 & 6,5 & $27.100 \pm 4.300$ \\
\hline
\end{tabular}

core sample obtained close to the shoreline in the Barrier IV, with an age of $10.630 \pm 110 \mathrm{cal}$ yrs BP. These data indicate that the upper formation was modified probably during the wet phase in the early Holocene. The articulated bivalve dated by radiocarbon (indicated in the Figure $7 \mathrm{c}$ ) provided an age of $100 \pm 30 \mathrm{yrs}$ BP $(2 \sigma$ Cal BP 225-250 yrs), thus indicating that portions of the upper Cordão Formation were eroded by fluvial systems developed in the late Holocene.

The luminescence ages presented here indicate that the Cordão Formation was deposited between $\sim 30$ and 10 kyrs ago, during the last glacial stage, or marine isotope stage (MIS) 2, and put this unit in chronostratigraphic correlation with the Luján (Guerrero Member), Tezanos Pinto, Teodelina, and Urundel formations of Argentina, and the Dolores Formation of Uruguay (Iriondo 1997, Tonni et al. 1999, 2003, Sayago et al. 2001, Zárate 2003, Veroslavsky 2004, Munyikwa 2005, Iriondo and Kröhling 2007b, Frechen et al. 2009, Corona et al. 2013, Ubilla et al. 2011, Ubilla and Rinderknecht 2014).

\section{DISCUSSION}

The presence of silty sediments at or close to the surface in the CPRS was reported by other authors. Delaney (1962) considered that this silt represents the continuity of loess deposits found to the west, in the Province of Entre Ríos (northern Argentina), which extended through Uruguay and the southern Rio Grande do Sul. In the first stratigraphic survey of Chuy Creek, Soliani (1973) followed this interpretation and considered that the calichebearing silty layer was formed by a combination of local pedogenesis and deposition of wind-blown fine material transported from periglacial areas of Argentina. He then concluded that the silt was loessic in origin, represented the latest Pleistocene (Wisconsin) glaciation, and was correlated to the 'Pampean' Formation of Argentina and to the Libertad Formation of Uruguay.

The OSL ages presented here indicate that the deposition of the Cordão Formation began at or close to the onset of the last glacial stage (MIS 2), around 29 kyrs ago (Lisiecki and Raymo 2005). Most of this interval encompasses the Last Glacial Maximum (LGM), recorded from 25 to 14 kyrs ago in the Southern Hemisphere (Heusser 1990, Rabassa et al. 2005, Ehlers and Gibbard 2007, Clark et al. 2009). The onset of deposition of loess in the CPRS followed the advance of the Andean glaciers located between $30^{\circ}-40^{\circ} \mathrm{S}$, which began around 35-40 kyrs ago (Zech et al. 2008).

\section{ORIGIN AND MECHANISMS OF DEPOSITION}

Although the mechanisms that produce silt-sized particles found in loess deposits are object of discussion, the most accepted explanations assume the comminution of particles by mechanical grinding by rivers or glaciers, or physico-chemical weathering in desert environments as the dominant processes (Smalley 1966, 1971, Wright 2001). The upward increase in silt observed in the banks of Chuy Creek raised questions about its origin, because the physical conditions in southern Brazil are not suitable for an in situ formation of this material. Moreover, the Lagoon System III does not receive sediment input from rivers since the middle Pleistocene, when the Barrier II was formed (Villwock and Tomazelli 1995). From then on, the only local sources of sediment 
would be the subaerial portions of the Barriers II and III, which could supply the material through aeolian transportation, mass movement or water flowing from wetlands developed on top of the barriers. The small amount of fine (mostly clay) sediments in the barriers, however, precludes these units as the source of the silt-sized particles of the Cordão Formation, although they may have supplied the sand-sized particles, as indicated by the similar mineral content. The barriers probably acted as topographic obstacles, trapping the loess within the Lagoon System III and preventing its re-mobilization. Local topography exerts a major influence on the deposition of loess, especially in areas of sparse vegetation (Mason et al. 1999).

It is likely that the loess was transported from distant areas to the southern CPRS by long-term aeolian suspension. In South America, Africa and Australia, the warm and humid conditions that characterized the interstadial stage between >30 and 40 kyrs ago (MIS 3) were followed by dry and cold climate, with widespread aeolian processes until about $18 \mathrm{ka} \mathrm{BP}$ (Stute et al. 1995, Munyikwa 2005). Several geological records show that during MIS 2 southern South America was subject to increased aeolian processes (Figure 9). The westerly winds (Westerlies) generated by the South Pacific Anticyclone that today are restricted to latitudes higher than $40^{\circ} \mathrm{S}$, reached up to $30^{\circ} \mathrm{S}$ during MIS 2 (Lamy et al. 1998, Kaiser et al. 2005) and were intensified because of the northwards shift of the polar front (Sayago et al. 2001). In addition, the greater northwards extent of the Patagonian glaciers, reaching up to $28^{\circ} \mathrm{S}$, probably accelerated the Westerlies as they crossed the ice fields, generating intense leeward katabatic winds (Clapperton 1993a, Hulton et al. 1994, Iriondo 1997, 1999b, Kumar 2011). These winds caused northeastwards deflation of the loess belt that surrounds the Pampean Sand Sea. This loess was generated and deposited at the foothills of the Andes during the prior glacial stages (MIS

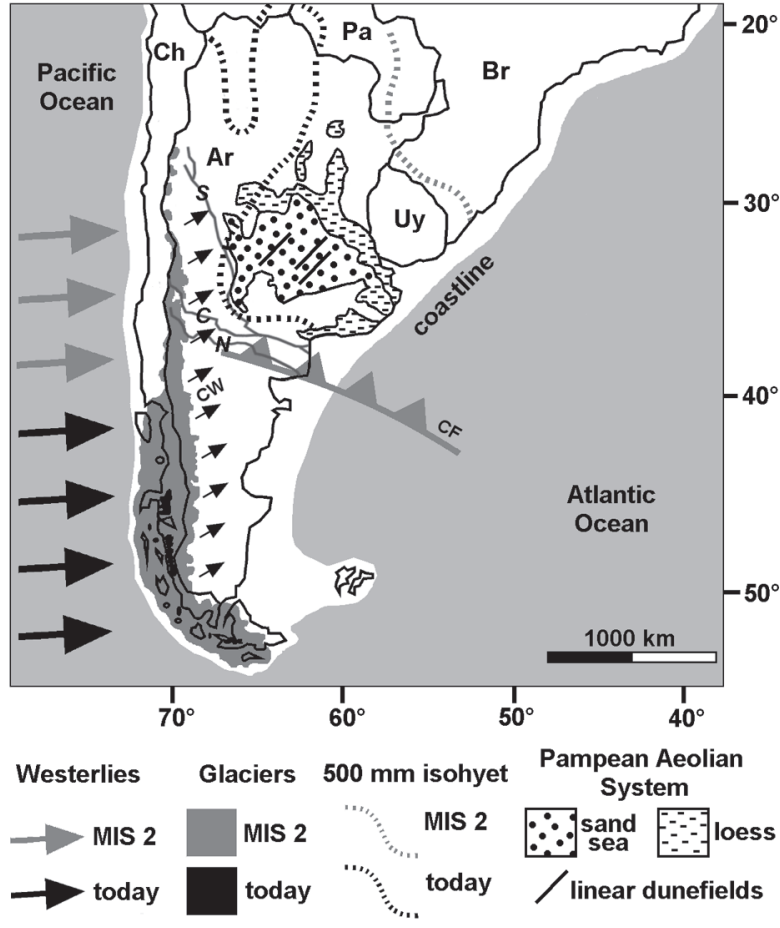

Figure 9 - Environmental conditions in southern South America during MIS 2: the combination of the northwards shifted Westerlies, increased cathabatic winds from the Andes $(\mathrm{CW})$ and cold fronts $(\mathrm{CF})$, resulted in cooling and enhanced aeolian processes, which promoted the northeasterly deflation of the Pampean loess generated in the Andes and distributed by the Salado $(S)$, Colorado $(C)$ and Negro $(N)$ rivers. The coastline located some $100 \mathrm{~km}$ farther to the east increased the effects of continentality. These factors would have pushed semiarid conditions (limited by the $500 \mathrm{~mm}$ isohyet) some $\sim 750 \mathrm{~km}$ to NE (Ar: Argentina, Br: Brazil, Ch: Chile, Pa: Paraguay, Uy: Uruguay; modified from Iriondo 1997).

4 and 6), redistributed along the floodplains of the Salado, Negro and Colorado rivers during the intervening stages (MIS 5 and 3) and accumulated in the Pampean Aeolian System by aeolian processes (Clapperton 1993a, Iriondo and Garcia 1993, Iriondo 1999b, Zárate and Tripaldi 2012). The presence and orientation of long linear dunes found in the Pampean Sand Sea indicates prevailing anticyclonic winds from SSW during the LGM (Iriondo 1997, 1999b, Carignano 1999).

Delaney (1962) proposed that the silt-sized particles found in the CPRS were transported from loess deposits found in the province of Entre 
Ríos (northern Argentina), located westwards of Rio Grande do Sul. Considering the prevailing winds from SSW during MIS 2, however, the most likely source areas for the loess found in the CPRS would have been located to the south. Although some areas of southwestern Brazil, northeastern Argentina, northern Uruguay, Paraguay and Bolivia are covered by tropical loess (Iriondo and Kröhling 2007a), its physical properties (silty clay, dark red color, clay fraction consisting mostly of quartz and kaolinite) are distinct from the loess found in the CPRS. Besides, the absence of fluvial connection between those areas and the CPRS indicates that it is unlikely that tropical loess could have been transported to the latter.

One possible source could be the Pleistocene loessic formations of Uruguay (Libertad I, II and Dolores). The carbonate-rich $\mathrm{C}$ soil horizons (CCa) found in the Touro Passo Formation (in western Rio Grande do Sul), in the southern-central part of the state, and in the CPRS, described by Bombin and Klamt (1974) and regarded as of loessic origin, exhibit spatial correlation with loess deposits of northern and northeastern Uruguay (Panario and Gutiérrez 1999; Figure 10). The LibertadIFormation consists of carbonate-rich massive aeolian deposits formed under cold and dry climate, with illite as the dominant clay mineral, while Libertad II exhibits $\mathrm{B}$ horizons and is richer in clay minerals, mostly montmorillonite, indicating deposition under warm and humid climate (Panario and Gutiérrez 1999). The Dolores Formation covers large areas along the western bank of Mirim Lake, in Uruguayan territory, and Veroslavsky et al. (2004) observed that the Libertad I and Dolores formations may be the same unit. Following this rationale, the chronostratigraphic correlation between the Dolores/Libertad I and the Cordão formations, as deduced from the ages presented here, indicates that all were deposited at the same epoch, therefore may share a common origin, namely the loess belt surrounding the Pampean Sand Sea of Argentina.

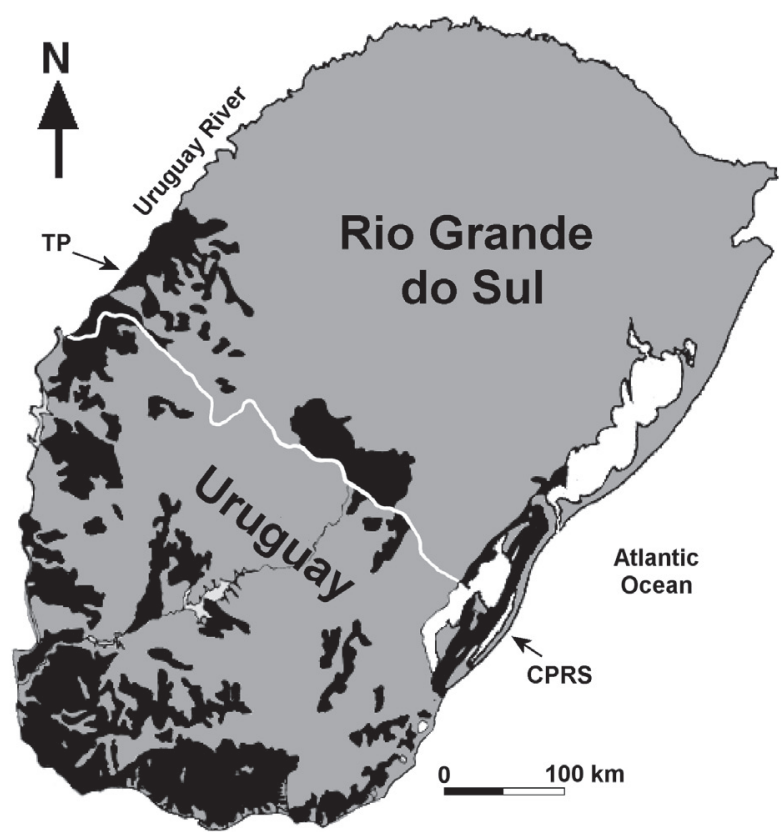

Figure 10 - Distribution of loess deposits in Uruguay (from Panario and Gutiérrez 1999) and soils with CCa horizons (interpreted to be of loessic origin) in Rio Grande do Sul state (from Bombin and Klamt 1974). TP = Touro Passo Formation.

The Pampa landscape stretches between the Buenos Aires Province of Argentina and the Rio Grande do Sul state. In this area there are no mountains or high plateaus that could act as a barrier for the southerly winds. The enhanced aeolian activity in the Pampas during glacial stages could have deflated and transported silt- and clay-sized particles from deposits of the Pampean Aeolian System that were generated during the previous glacial stages up to Uruguay and southern Brazil. Following this rationale, the loess of the Cordão and Dolores formations would have been formed by material that was generated during the penultimate glacial epoch (MIS 4) (Iriondo 1999a, Kröhling 1999), thereforte it can be classified as secondary (or reworked) loess .

Wind velocities of 0,2 to $0,6 \mathrm{~m} / \mathrm{s}^{-1}$ are capable of entrain and transport coarse- to fine-sized silt a few meters above the ground by long-term suspension (Tsoar and Pye 1987, Pye 1987). Sayago et al. (2001) proposed that the transportation of loess from the 
Argentinean Pampas involved the combination of low-altitude strong winds, which transported the particles by suspension for short periods, and the vertical advection and redistribution of fine particles by high-altitude westerlies and jet streams.

\section{MINERAL COMPOSITION AND PALEOCLIMATE}

The clay mineral assemblage of the Cordão Formation is similar to that of loessic sediments found in some areas of the Pampean Region, which indicates an origin from volcanic rocks (Teruggi 1957, Zárate 1991, Morrás 2003, Kemp et al. 2006). The coarse assemblage is similar to those of the Barriers II and III, suggesting some contribution from these units. In fact, the stratigraphic succession observed in the Barrier III shows that the subaerial portion of this unit was subject to aeolian processes from $\sim 90$ to $10.5 \mathrm{kyrs}$ ago, when it was stabilized by pedogenesis (Poupeau et al. 1988, Lopes et al. 2015).

Because clay minerals suffer minimal changes in composition (mostly ion-exchange reactions) during transportation and deposition (Eberl 1984), the clays found in the loess are inherited from the parent material rather than produced by neoformation or transformation. Illite is a common clay mineral in the late Pleistocene Pampean loess (González Bonorino 1966, Camillión 1993, Sayago 1995, Kröhling and Orfeo 2002, Iriondo and Kröhling 2007a). The 'Pampean Formation' was divided in two zones: the upper contains caliche horizons, illite as the dominant clay mineral and is derived from Precambrian and 'Tertiary' rocks; the lower is formed by material derived from alteration of Triassic lavas and is dominated by montmorillonite and kaolinite (González Bonorino 1966).

Illite is a potassium aluminous mica-like mineral that in continental environments can be formed in soils derived from acidic rocks, in areas where precipitation is below $500 \mathrm{~mm}$, and remains stable during short-term fluvial transportation
(Ferrando and Daza 1974, Velde 1985). The origin of the interstratified illite/smectite in the Cordão Formation could be either aeolian transportation or neoformation. The rate of formation of interstratified illite/smectite from muscovite is faster in soils, probably due to the extra energy input from plants (Velde and Meunier 2008).

Pedogenic carbonate, in the form of nodules and concretions is a common feature in semi-arid environments, including loess deposits (Teruggi 1957, Smalley 1966, Pécsi 1990). Darwin (1846, Chap. IV) described that the sediments of the Pampean Formation usually contained horizons of 'toscas', formed by carbonate with nodular or stalactiform shapes (= rhizocretions?). The depth at which the pedogenic carbonate is formed exhibits negative correlation with regional precipitation, and usually occurs in places where the mean annual average precipitation does not exceed $500 \mathrm{~mm}$ (Kholodov 2007, Tófalo and Morrás 2009).

Delaney (1965) regarded the "Caliche Cordão" as the product of a pedogenetic phase developed under cold and dry climate. This assumption was discussed by Bombin and Klamt (1974), who stated that although the caliche indicates dry conditions, it did not necessarily represent cold climate. They compared the carbonate-rich silty soils of the CPRS with similar deposits found in southern and western Rio Grande do Sul, and concluded that such soils were of Holocene age, formed during a warm and dry interval between 3.5 and 2.4 kyrs ago, also recorded in other areas of southern Brazil, but without providing absolute ages.

During MIS 2 arid and semiarid environments occupied about $25 \%$ of South America (Clapperton 1993a). The sea-level drop of some $120 \mathrm{~m}$ below present-day level during this interval would have increased continentality, thus further contributing for dry conditions. In southern South America, the climatic belts were shifted up to $\sim 750 \mathrm{~km}$ to the northeast in response to the eastwards migration of the Pacific anticyclone (Clapperton 1993a, b, 
Iriondo 1999b, Ab'Saber 2000, Rabassa et al. 2005). This implies that the $500 \mathrm{~mm}$ isohyet that today is found to the southwest of the Pampean Region may have reached up to Uruguay and southern Brazil, as has been proposed by other authors (Clapperton 1993b, Ab'Saber 2000, Zárate 2006). This assertion is supported by the presence of fossils of rodents regarded as indicators of arid and semiarid conditions (Dolichotis, Microcavia) in the Dolores Formation of Uruguay (Ubilla et al. 2011, Corona et al. 2013) and also in Chuy Creek (Ubilla et al. 2008, Kerber et al. 2011).

Paleoclimatic data obtained from a speleothem collected in a cave located some $900 \mathrm{~km}$ to the north of Chuy Creek indicate that precipitation in southern Brazil is controlled by insolation maxima and minima, and suggest an increase in summer monsoon (SASM) rainfall (of tropical origin) in southern Brazil between 40 an 17 kyrs ago, probably caused by a southward shift of the South America Convergence Zone (SACZ) forced by the expansion of ice in the Northern Hemisphere (Cruz et al. 2005). The apparent discrepancy between those results and the records of dry environments in the southern CPRS at that interval could be explained if those conditions caused increased seasonality of rainfall, with contrasting wet and dry seasons, or if the total amount of summer rainfall of tropical origin that reached areas to the south was much lower than in the area where the cave is located. In fact, the city of Porto Alegre, located nearly $500 \mathrm{~km}$ to the north of Chuy Creek, today receives less precipitation during summer, when the SASM is intensified due to the southwards shift of the SACZ (Cruz et al. 2005).

The iron-manganese nodules and iron oxide mottlings are redoximorphic features, formed by the concentration and oxidation of manganese and iron related to variations of moisture availability (Vepraskas and Lindbo 2012). Alternate seasonal cycles of wetting and drying are the main control on the mineral dissolution and precipitation of manganese and iron oxides in soils, which lead to the formation of iron-manganese nodules (Sanz et al. 1996, Stiles et al. 2001). Therefore, the presence of such nodules in the Cordão Formation could indicate seasonal rainfall regime during the last glacial epoch.

\section{MAGNETIC SUSCEPTIBILITY (MS)}

The values of MS in continental sediments are useful proxies for estimating paleoclimatic conditions (Heller and Evans 1995, Maher 1998, Balsam et al. 2011). In loessic sequences, MS variations usually result from differences between paleosoils (developed under wetter/warmer conditions) and loess (deposited under drier/cooler conditions), but this pattern is variable between sites. In Argentina, for example, low MS indicates paleosoils and higher MS is found in loess (Orgeira et al. 1998, Schellenberger et al. 2003), while in the Chinese Loess Plateau the pattern is the opposite (An et al. 1991, Zhang et al. 2003).

The source of MS signal in sediments is controlled mainly by the presence of the ferrimagnets magnetite $\left(\mathrm{Fe}_{3} \mathrm{O}_{4}\right)$ and maghemite $\left(\gamma \mathrm{Fe}_{2} \mathrm{O}_{3}\right)$, whose presence and concentration in soils/loess is seemingly related to pedogenesis and dust transport, which in turn are controlled by the climate (Maher 1998). During wetter/warmer periods, pedogenesis would increase the concentration of ferrimagnets in the soil, while drier/cooler conditions would favor the dilution of ferromagnetic particles in the aeolian deposited dust (Balsam et al. 2011). The higher MS values in loess than in paleosoils in deposits of Argentina and Alaska, seems to be related to the proximity of these areas to ice mantles during glacial maxima, which would allow for increased aeolian transport capable of carrying larger magnetic grains (Heller and Evans 1995).

The MS values of the Cordão Formation are lower than those found in recent sandy soils developed on top of the Barrier III (Table I). The high MS values in the uppermost 15 centimeters 
of the Barrier III profile are probably related to the presence of modern vegetation, because magnetotactic bacteria associated with plant roots may have an important role in the formation of ultrafine magnetite grains in soils (Maher 1998). The formation and/or concentration of iron oxides is related to the presence of vegetation, possibly through the activity of bacteria in the roots, therefore the low MS values found in the loess could indicate a reduction in the plant cover. In the lower layer of the formation, the higher MS values were measured close to the top, probably because of the presence of iron-manganese nodules and iron oxide halos surrounding plant roots.

\section{ACCUMULATION RATES}

Despite the absence of distinct paleosoils interbedded with the loess of the southern CPRS, the laminations observed in the outcrop shown in Figure 2 suggest variations in depositional conditions such as moisture availability, and/ or rates of accumulation. Interbedded layers of paleosoils and loess are a common feature in several Pampean deposits, and indicate alternation between warm/humid and cold/dry phases, respectively (Zinck and Sayago 1999, 2001, Muhs and Bettis 2003, Frechen et al. 2009). Although most paleosoil-loess sequences represent longperiod climatic oscillations (Schellenberger and Veit 2006), in the Tucumán Province of northern Argentina the sequences developed between 27.6 and $17.5 \mathrm{kyrs}$ ago indicate a climatic periodicity of 500 years (Zinck and Sayago 1999). The absence of well-developed paleosoils within the loess of the southern CPRS suggests reduced vegetation cover, probably related to dry and cold conditions throughout the time of its deposition.

Despite the uncertainties, the two OSL ages obtained from samples collected with a vertical separation of $\sim 80$ centimeters, represent an interval of approximately 1.100 years. Because no hiatuses or unconformities were observed between the two samples, deposition can be regarded as continuous throughout this interval, with an estimated accumulation rate (AR) of $0,0007 \mathrm{~m} / \mathrm{yr}$. This rate was used to calculate the mass accumulation rate (MAR) using the relationship (Kohfeld and Harrison 2001):

$$
\mathrm{MAR}=\mathrm{AR} \times f \times \mathrm{BD}
$$

where $f$ is the fraction of aeolian transported material (loess $=1$ ) and $\mathrm{BD}$ is the bulk density of the material $\left(0,9 \times 10^{6} \mathrm{~g} / \mathrm{m}^{3}\right.$ for the loess from the Cordão Formation). The estimated MAR for this unit was $630 \mathrm{~g} / \mathrm{m}^{2} / \mathrm{yr}$, within the range of rates found for European $\left(100-7.000 \mathrm{~g} / \mathrm{m}^{2} / \mathrm{yr}\right)$ and Chinese (60 to $>5.000 \mathrm{~g} / \mathrm{m}^{2} / \mathrm{yr}$ ) loess, but lower than the estimated for loess units in North America $\left(>2.000 \mathrm{~g} / \mathrm{m}^{2} / \mathrm{yr}\right.$ ) during MIS 2 (Frechen et al. 2003, Kohfeld and Harrison 2003, Roberts et al. 2003, Lai et al. 2007).

\section{PALEOENVIRONMENT}

Large-bodied mammals such as ground sloths, glyptodonts, mastodonts and toxodonts, although common in the fluvial facies of the underlying Santa Vitória Formation, have not been found in the Cordão Formation so far. The loessic units of Argentina and Uruguay, on the other hand, are well-known for the presence of large mammalian remains (Darwin 1846, Teruggi 1957, Zárate and Blasi 1991, Ferrero 2009, Ubilla et al. 2011, Corona et al. 2013).

Cold and dry climate was widespread in southern South America at the time of deposition of the Cordão Formation. Paleoclimatic reconstructions and pollen remains indicate that the pampas were then occupied by steppes (Clapperton 1993a, Behling and Lichte 1997, Behling 2002, Behling et al. 2005). The absence of pollen remains and the scarcity of vertebrate fossils in the Cordão Formation could be explained by the lack of depositional environments that favor the preservation of fossil remains, such as fluvial 
systems and lakes, because of the dry climate. Such conditions alone, however, do not explain the absence of large and weathering-resistant skeletal elements such as bones and teeth of megamammals, therefore ecological factors are probably involved.

Fossils of rodents that indicate semiarid environments (Microcavia and Dolichotis) have also been found in Chuy Creek (Ubilla et al. 2008, Kerber et al. 2011), but their precise stratigraphic provenance is unknown. The only identified fossil that was collected directly from the loess is the maxila of Hemiauchenia (Figure 8a). Morphological and isotopic analyses show that these animals were mostly browsers, but could also adapt to local environments and assume a grazing habit (Feranec 2003, Semprebon and Rivals 2010, Yann and DeSantis 2014). It is likely that the more generalist dietary habit of Hemiauchenia enabled these animals to survive under cold dry conditions that were unsuitable for other large mammals.

Although an absolute age for the end of loess deposition in the CPRS is not available yet, the ${ }^{14} \mathrm{C}$ ages from the organic matter-rich clayey silt layers described by Lima et al. (2013) and Caron (2014) show that by $\sim 10$ kyrs ago wetter conditions were widespread in the area. Those ${ }^{14} \mathrm{C}$ ages correlate this wet interval to the Hypsithermal or climatic optimum at the early-middle Holocene (Emiliani 1972, Ciais et al. 1992, Iriondo 1999b), which was characterized by widespread pedogenesis in the Pampas (Kröhling 1999, Tonni et al. 2001, Iriondo and Kröhling 2007b, Zárate et al. 2009).

Wet conditions after the deposition of loess in the CPRS are also evidenced by the lenticular bodies of diatomite that outcrop along the banks of Chuy Creek, at the boundary between the lower and upper Cordão Formation (see Figure 7). These diatomites measure up to $\sim 1$ meter across, have a maximum thickness of $\sim 30$ centimeters and exhibit laminations, which may indicate seasonal climate. The accumulation of diatom frustules points to high primary productivity (Lopes et al. 2016b), and the lenticular shape of the diatomites suggests that these were formed in ponds that filled small deflation basins, under conditions of reduced input of terrigenous clastic sediments, because these promote the dissolution of the frustules (Harwood, 1999).

\section{ACKNOWLEDGMENTS}

The authors express their gratitude to Dr. Carolina S. Scherer (Universidade Federal do Recôncavo da Bahia) for identifying the specimen of Hemiauchenia, to Edgar Bercht for the X-ray diffractometry analyses, to Rudimar Krumreick and Erica Silveira (CEME-Sul) for the EDS analysis and MEV imaging, to Eletrosul-Centrais Elétricas S/A for the access to data from the boreholes and to Dr. Marcelo Zárate (CONICET-UNLPAM) and other anonymous referee for their important revisions to the manuscript. This research was possible by the finantial support from the Conselho Nacional de Desenvolvimento Científico e Tecnológico (CNPq) (Doctorship and Postdoctoral grant, Process 150153/2014-7, for the senior author).

\section{REFERENCES}

AB'SABER AN. 2000. Spaces occupied by the expansion of dry climates in South America during the Quaternary ice ages. Rev Inst Geol 21: 71-78.

AN Z, KUKLA GJ, PORTER SC AND XIAO J. 1991. Magnetic susceptibility evidence of monsoon variation on the loess plateau of central China during the last 130,000 years. Quatern Int 36: 29-36.

BALSAM WL, ELLWOOD BB, JI J, WILLIAMS ER, LONG X AND EL HASSANI A. 2011. Magnetic susceptibility as a proxy for rainfall: worldwide data from tropical and temperate climate. Quaternary Sci Rev 30: 2732-2744.

BEHLING H. 2002. South and southeast Brazilian grasslands during Quaternary times: a synthesis. Palaeogeogr Palaeocl Palaeoecol 177: 19-27.

BEHLING H AND LICHTE M. 1997. Evidence of dry and cold climatic conditions at glacial times in tropical southeastern Brazil. Quaternary Res 48: 348-358.

BEHLING H, PILLAR VD AND BAUERMANN SG. 2005. Late Quaternary grassland (campos), gallery forest, 
fire and climate dynamics, studied by pollen, charcoal and multivariate analysis of the São Francisco de Assis core in western Rio Grande do Sul (southern Brazil). Rev Palaeobot and Palyno 133: 235-248.

BEHRENSMEYER AK. 1978. Taphonomic and ecologic information from bone weathering. Paleobiology 4(2): $150-162$.

BOMBIN M. 1976. Modelo paleoecológico evolutivo para o Neoquaternário da Campanha - oeste do Rio Grande do Sul (Brasil). A Formação Touro Passo, seu conteúdo fossilífero e a pedogênese pós-deposicional. Universidade Federal do Rio Grande do Sul, Programa de Pós-Graduação em Geociências, MSc Dissertation, 133 p. (Unpublished).

BOMBIN M AND KLAMT E. 1974. Evidências paleoclimáticas em solos do Rio Grande do Sul. In: Congresso Brasileiro de Geologia, 28, 1974, Porto Alegre. Anais 3: 183-193.

CAMILLIÓN MC. 1993. Clay mineral composition of Pampean loess (Argentina). Quatern Int 17: 27-31.

CARIGNANO CA. 1999. Late Pleistocene to recent climate change in Córdoba Province, Argentina: geomorphological evidence. Quatern Int 57/58: 117-134.

CARON F. 2007. Depósitos sedimentares associados à desembocadura do Arroio Chuí (Planície Costeira do Rio Grande do Sul e suas relações com as variações do nível do mar durante o Holoceno. Programa de Pós-Graduação em Geociências - Universidade Federal do Rio Grande do Sul (PPGGEO-UFRGS). M. Sc. Dissertation, 81 p. Available at http://www.lume.ufrgs.br/hdl.handle.net/10183/8813 (Unpublished).

CARON F. 2014. Estratigrafia e evolução da barreira holocênica na região costeira de Santa Vitória do Palmar, Planície Costeira do Rio Grande do Sul. Programa de Pós-Graduação em Geociências - Universidade Federal do Rio Grande do Sul (PPGGEO-UFRGS). Ph.D. Thesis, 167 p. Available at http://www.lume.ufrgs.br/hdl.handle. net/10183/88625

CIAIS P, PETIT JR, JOUZEL J, LORIUS C AND BARKOV NI. 1992. Evidence for an early Holocene climatic optimum in the Antarctic deep ice-core record. Clim Dynam 6: 169-177.

CLAPPERTON CM. 1993a. Nature of environmental changes in South America at the Last Glacial Maximum. Palaeogeogr Palaeocl Palaeoecol 101: 189-208.

CLAPPERTON CM. 1993b. Quaternary Geology and Geomorphology of South America. Amsterdam, Elsevier Press, 779 p.

CLARK PU, DYKE AS, SHAKUN JD, CARLSON AE, CLARK J, WOHLFARTH B, MITROVICA JX, HOSTETLER SW AND MCCABE AM. 2009. The Last Glacial Maximum. Science 325: 710-714.

CORONA A, PEREA D AND MCDONALD HG. 2013. Catonyx cuvieri (Xenarthra, Mylodontidae, Scelidotheriinae) from the late Pleistocene of Uruguay, with comments regarding the systematics of the subfamily. J Vertebr Paleontol 33(5): 1214-1225.

CRUZ FW, BURNS SJ, KARMANN I, SHARP WD, VUILLE M, CARDOSO AO, FERRARI JA, DIAS PLS AND VIANA O. 2005. Insolation-driven changes in atmospheric circulation over the past 116,000 years in subtropical Brazil. Nature 434: 63-66.

D'ORBIGNY A. 1842. Voyage dans l'Amérique Méridionale, tome. 3, 3 partie, Géologie. Paris, Chez P. Bertrand, 298 p.

DARWIN CR. 1846. Geological Observations on South America. London, Smith, Elder and Co., 279 p.

DELANEY PJV. 1962. Quaternary Geologic History of the Coastal Plain of Rio Grande do Sul, Brazil. South American Coastal Studies Technical Reports 18(Part A): 63.

DELANEY PJV. 1965. Fisiografia e Geologia de Superfície da Planície Costeira do Rio Grande do Sul. Escola de Geologia UFRGS Publicação Especial no. 6, 105 p.

DILLENBURG SR AND BARBOZA EG. 2014. The strikefed sandy coast of southern Brazil. In: Martini IP and Wanless HR (Eds), Sedimentary Coastal Zones from High to Low Latitudes: Similarities and Differences. Geological Society Special Publications 388.

EBERL DD. 1984. Clay mineral formation and transformation in rocks and soils. Philos T Roy Soc A 311: 241-257.

EHLERS J AND GIBBARD PL. 2007. The extent and chronology of Cenozoic Global Glaciation. Quatern Int 164-165: 6-20.

EMILIANI C. 1972. Quaternary hypsithermals. Quaternary Res 2: 270-273.

FERANEC RS. 2003. Stable isotopes, hypsodonty, and the paleodiet of Hemiauchenia (Mammalia: Camelidae) a morphological specialization creating ecological generalization. Paleobiology 29(2): 230-242.

FERRANDO LA AND DAZA M. 1974. Mineralogía de la fracción arcillosa de la Formación Fray Bentos en el suroeste del Uruguay. In: Congresso Brasileiro de Geologia, 28, Porto Alegre, Anais 5: 3-13.

FERRERO BS. 2009. Mamíferos del Cuaternario de la provincia de Entre Ríos, Argentina: Diversidad y evolución. Aspectos bioestratigráficos y paleozoogeográficos de una fauna particular. Facultad de Ciencias Naturales y Museo Universidad Nacional de La Plata, Ph.D. Thesis, 424 p.

FOLK RL. 1980. Petrology of Sedimentary Rocks. Austin, Hemphill Publishing Co., 182 p.

FRECHEN M, OCHES EA AND KOHFELD KA. 2003. Loess in Europe - mass accumulation rates during the Last Glacial Period. Quaternary Sci Rev 22: 1835-1857.

FRECHEN M, SEIFERT B, SANABRIA JA AND ARGÜELLO GA. 2009. Chronology of the late Pleistocene Pampa loess from the Córdoba area in Argentina. J Quaternary Sci 24(7): 761-722.

GOMES A, TRICART JLF AND TRAUTMANN J. 1987. Estudo Ecodinâmico da Estação Ecológica do Taim e seus Arredores. Porto Alegre, Editora da UFRGS, 84 p. 
GONZÁLEZ BONORINO F. 1966. Soil clay mineralogy of the Pampa plains, Argentina. J Sediment Petrol 36(4): 1026-1035.

HARWOOD DM. 1999. Diatomite. In: Stoermer EF and Smol JP (Eds), The Diatoms: Applications for the Environmental and Earth Sciences. Cambridge University Press, p. 436-443.

HELLER F AND EVANS ME. 1995. Loess magnetism. Rev Geophys 33(2): 211-240.

HEUSSER CJ. 1990. Chilotan piedmont glacier in the southern Andes during the Last Glacial Maximum. Rev Geol Chile 17(1): 3-18.

HULTON N, SUGDEN D, PAYNE A AND CLAPPERTON C. 1994. Glacier modeling and the climate of Patagonia during the Last Glacial Maximum. Quat Res 42: 1-19.

IRIONDO MH. 1997. Models of deposition of loess and loessoids in the Upper Quaternary of South America. J S Am Earth Sci 10(1): 71-79.

IRIONDO MH. 1999a. The origin of silt particles in the loess question. Quatern Int 62: 3-9.

IRIONDO MH. 1999b. Climatic changes in the South American plains: records of a continental-scale oscillation. Quatern Int 57/58: 93-112.

IRIONDO MH AND GARCIA NO. 1993. Climatic variations in the Argentine plains during the last 18,000 years. Palaeogeogr Palaeocl Palaeoecol 101: 209-220.

IRIONDO MH AND KRÖHLING DM. 2007a. Nonclassical types of loess. Sediment Geol 202: 352-368.

IRIONDO MH AND KRÖHLING DM. $2007 \mathrm{~b}$. Geomorfología y sedimentología de la cuanca superior del Rio Salado (sur de Santa Fé y noroeste de Buenos Aires, Argentina). Lat Am J Sediment Bas Anal 14(1): 1-23.

JOST H. 1975. Cenozoic stratigraphy of the Rio Grande do Sul coastal province, SE Brazil. Bol Paran Geoci 33: 54-55.

KAISER J, LAMY F AND HEBBELN D. 2005. A 70-ka sea surface temperature record off southern Chile (Ocean Drilling Program Site 1233). Paleoceanography 20 PA4009.

KEMP RA, ZÁRATE M, TOMS P, KING M, SANABRIA J AND ARGUELLO G. 2006. Late Quaternary paleosoils, stratigraphy and landscape evolution in the Northern Pampa, Argentina. Quaternary Res 66(1): 119-132.

KERBER L, LOPES RP, VUCETICH MG, RIBEIRO AM AND PEREIRA J. 2011. Chinchillidae and Dolichotinae rodents (Rodentia, Hystricognathi, Caviomorpha) from the late Pleistocene of southern Brazil. Rev Bras Paleontol 14(3): 229-238.

KHOLODOV VN. 2007. Caliches: a newly-formed boundary carbonate material in soils. Lithol Min Res 42(3): 246-256.

KLAPPA CF. 1980. Rhizoliths in terrestrial carbonates: classification, recognition, genesis and significance. Sedimentology 27: 613-629.

KOHFELD KE AND HARRISON SP. 2001. DIRTMAP: the geological record of dust. Earth-Sci Rev 54: 81-114.
KOHFELD KE AND HARRISON SP. 2003. Glacialinterglacial changes in dust deposition on the Chinese Loess Plateau. Quaternary Sci Rev 22: 1859-1878.

KRÖHLING DM. 1999. Upper Quaternary geology of the lower Carcarañá Basin, North Pampa, Argentina. Quatern Int 57/58: 135-148.

KRÖHLING DM AND ORFEO O. 2002. Sedimentología de unidades loéssicas (Pleistoceno Tardío-Holoceno) del centro-sur de Santa Fe. Rev Asoc Argentina Sedimentol 9(2): 135-154.

KUMAR A. 2011. Katabatic wind: in relation with snow and glaciers. In: Singh VP, Singh P and Haritashya UK (Eds), Encyclopedia of Snow, Ice and Glaciers. Springer Science Business Media, Dordrecht, Netherlands, p. 671-672.

LAI ZP, WINTLE AG AND THOMAS DSG. 2007. Rates of dust deposition between $50 \mathrm{ka}$ and $20 \mathrm{ka}$ revealed by OSL dating at Yuanbao on the Chinese Loess Plateau. Palaeogeogr Palaeocl Palaeoecol 248: 431-439.

LAMY F, HEBBELN D AND WEFER G. 1998. Late Quaternary precessional cycles of terrigenous sediment input off the Norte Chico, Chile $\left(27.5^{\circ} \mathrm{S}\right)$ and paleoclimatic implications. Palaeogeogr Palaeocl Palaeoecol 141: 233251.

LATRUBESSE EM, STEVAUX JC, CREMON EH, MAY J-H, TATUMI SH, HURTADO MA, BEZADA M AND ARGOLLO JB. 2012. Late Quaternary megafans, fans and fluvio-aeolian interactions in the Bolivian Chaco, Tropical South America. Palaeogeogr Palaeocl Palaeoecol 356-357: 75-88.

LIMA LG, DILLENBURG SR, MEDEANIC S, BARBOZA EG, ROSA MLCC, TOMAZELLI LJ, DEHNHARDT BA AND CARON F. 2013. Sea-level rise and sediment budget controlling the evolution of a transgressive barrier in southern Brazil. J S Am Earth Sci 42: 27-38.

LISIECKI LE AND RAYMO ME. 2005. A PliocenePleistocene stack of 57 globally distributed benthic $\delta^{18} \mathrm{O}$ records. Paleoceanography 20 PA1003.

LOPES RP. 2013. Biostratigraphy of the Pleistocene fossiliferous deposits of southern Brazilian coastal area. J Mammal Evol 20: 69-82.

LOPES RP, BUCHMANN FSC, CARON F AND ITUSARRY MEG. 2009. Barrancas fossilíferas do Arroio Chuí, RS - Importante megafauna pleistocênica no extremo sul do Brasil. In: Winge M, Schobbenhaus C, Berbert-Born M, Queiroz ET, Campos DA, Souza CRG and Fernandes ACS (Eds), Sítios Geológicos e Paleontológicos do Brasil, vol. 2. CPRM Brasília, p. 355-362.

LOPES RP, DILLENBURG SR, CARON F AND BUCHMANN FSC. 2015. Stratigraphy of the last interglacial Barrier III in the southern coast of the state of Rio Grande do Sul, Brazil In: Congresso da Associação Brasileira de Estudos do Quaternário, 15, 2015, Imbé. Anais, p. 187-188. 
LOPES RP, DILLENBURG SR, SCHULTZ CL, FERIGOLO J, RIBEIRO AM, PEREIRA JC, HOLANDA EC, PITANA VG AND KERBER L. 2014. The sea-level highstand correlated to marine isotope stage (MIS) 7 in the coastal plain of the state of Rio Grande do Sul, Brazil. An Acad Bras Cienc 86: 1573-1595.

LOPES RP, DILLENBURG SR, SIAL AN, GUADAGNIN F AND CARON F. 2016a The Caliche Cordão of the southern coastal plain of Rio Grande do Sul, Brazil. In: Congresso Brasileiro de Geologia, 48, 2016, Porto Alegre. Resumos.

LOPES RP, KINOSHITA A, BAFFA O, FIGUEIREDO AMG, DILLENBURG SR, SCHULTZ CL AND PEREIRA JC. 2013. ESR dating of Pleistocene mammals and marine shells from the coastal plain of Rio Grande do Sul state, southern Brazil. Quatern Int 352: 124-134.

LOPES RP, OLIVEIRA LC, FIGUEIREDO AMG, KINOSHITA A, BAFFA O AND BUCHMANN FSC. 2010. ESR dating of Pleistocene mammal teeth and its implications for the biostratigraphy and geological evolution of the coastal plain, Rio Grande do Sul, southern Brazil. Quatern Int 212(2): 213-222.

LOPES RP, PEREIRA JC, SOUZA MS, RAUPP SV AND DILLENBURG SR. 2016b. Diatoms from late Pleistoceneearly Holocene diatomites of the southern coastal plain of Rio Grande do Sul state, Brazil. In: Congreso Latinoamericano de Paleontología, 9, 2016, Lima. Libro de Resúmenes, p. 125.

MAHER BA. 1998. Magnetic properties of modern soils and Quaternary loessic paleosoils: paleoclimatic implications. Palaeogeogr Palaeocl Palaeoecol 137: 25-54.

MASON JA, NATER EA, ZANNER CW AND BELL JC. 1999. A new model of topographic effects on the distribution of loess. Geomorphology 28: 223-236.

MORRÁS HJM. 2003. Distribución y origen de sedimentos loessicos superficiales d la Pampa norte en base a la mineralogía de arenas. Resultados preliminares. Rev Asoc Argentina Sedimentol 10(1): 53-64.

MUHS DR. 2006. Loess deposits, origins and properties. In: Elias SA (Ed), Encyclopaedia of Quaternary Science. Amsterdam, Elsevier Science, p. 1405-1418.

MUHS DR AND BETTIS III EA. 2003. Quaternary loesspaleosoil sequences as examples of climate-driven sedimentary extremes. GSA Special Paper 370: 53-74.

MUNYIKWA K. 2005. Synchrony of Southern Hemisphere Late Pleistocene arid episodes: a review of luminescence chronologies from arid aeolian landscapes south of the equator. Quaternary Sci Rev 24: 2555-2583.

ORGEIRA MJ, WALTHER AM, VÁSQUEZ CA, DI TOMMASO I, ALONSO S, SHERWOOD G, YUGUAN H AND VILLAS JFA. 1998. Mineral magnetic record of paleoclimate variations in loess and paleosoil from the
Buenos Aires Formation (Buenos Aires, Argentina). J S Am Earth Sci 11(6): 561-570.

PANARIO D AND GUTIÉRREZ O. 1999. The continental Uruguayan Cenozoic: an overview. Quatern Int 62: 75-84.

PAULA COUTO C AND CUNHA FLS. 1965. Nota preliminar sobre o reconhecimento geo-paleontológico do Rio Grande do Sul. Boletim da Divisão de Geologia e Mineralogia, DNPM, avulso no. 40, p. 49-50.

PÉCSI M. 1990. Loess is not just the accumulation of dust. Quatern Int 7/8: 1-21.

PEREIRA JC, LOPES RP AND KERBER L. 2012. New remains of late Pleistocene mammals from the Chuy Creek, southern Brazil. Rev Bras Paleontol 15(2): 228-239.

PETRI S, COIMBRA AM, AMARAL G, OJEDAY OJEDA HÁ, FÚLFARO VJ AND PONÇANO WL. 1986. Código Brasileiro de Nomenclatura Estratigráfica. Rev Bras Geoci 16(4): 370-415.

POUPEAU G, SOLIANI E, RIVERA A, LOSS EL AND VASCONCELLOS MBA. 1988. Datação por termoluminescência de alguns depósitos arenosos costeiros do último ciclo climático, no nordeste do Rio Grande do Sul. Pesquisas 21: 25-47.

PYE K. 1984. Loess. Progr Phys Geography 8: 176-217.

PYE K. 1987. Aeolian Dust and Dust Deposits. London, Academic Press, $334 \mathrm{p}$.

PYE K. 1995. The nature, origin and accumulation of loess. Quaternary Sci Rev 14: 653-667.

RABASSA J, CORONATO AM AND SALEMME M. 2005. Chronology of the Late Cenozoic Patagonian glaciations and their correlation with biostratigraphic units of the Pampean region (Argentina). J S Am Earth Sci 20: 81-103.

READING HG. 1986. Sedimentary Environments and Facies. London: Blackwell Scientific Publications, 615 p.

ROBERTS HM, MUHS DR, WINTLE AG, DULLER GAT AND ARTHUR BETIS III E. 2003. Unprecedented last-glacial mass accumulation rates determined by luminescence dating of loess from western Nebraska. Quaternary Res 59: 411-419.

ROESCH LFW, VIEIRA FCB, PEREIRA VA, SCHÜNEMANN AL, TEIXEIRA IF, SENNA AJT AND STEFENON VM. 2009. The Brazilian Pampa: a fragile biome. Diversity 1: 182-198.

ROSA MLCC. 2012. Geomorfologia, estratigrafia de sequências e potencial de preservação dos sistemas Laguna Barreira do Quaternário Costeiro do Rio Grande do Sul. Programa de Pós-Graduação em Geociências - Universidade Federal do Rio Grande do Sul (PPGGEO-UFRGS). Ph.D. Thesis, 232 p. Available at http://www.lume.ufrgs. $\mathrm{br} /$ handle/10183/66367

SANZ A, GARCIA-GONZÁLEZ MT, VIZCAYNO C AND RODRIGUEZ R. 1996. Iron-manganese nodules in a semi-arid environment. Aust J Soil Res 34: 623-634.

SAYAGO JM. 1995. The Argentine neotropical loess: an overview. Quaternary Sci Rev 14: 755-766. 
SAYAGO JM, COLLANTES MM, KARLSON A AND SANABRIA J. 2001. Genesis and distribution of the Late Pleistocene and Holocene loess of Argentina: a regional approximation. Quatern Int 76/77: 247-257.

SCHELLENBERGER A, HELLER F AND VEIT H. 2003. Magnetostratigraphy and magnetic susceptibility of the Las Carreras loess-paleosoil sequence in Valle de Tafi, Tucumán, NW-Argentina. Quatern Int 106-107: 159-167.

SCHELLENBERGER A AND VEIT H. 2006. Pedostratigraphy and pedological and geochemical characterization of Las Carreras loess-paleosoil sequence, Valle de Tafí, NW-Argentina. Quaternary Sci Rev 25: 811831.

SCHERER CS, FERIGOLO J, RIBEIRO AM AND CARTELLE C. 2007. Contribution to the knowledge of Hemiauchenia paradoxa (Artiodactyla, Camelidae) from the Pleistocene of southern Brazil. Rev Bras Paleontol 10(1): 35-52.

SCHMITZ PI, GIRELLI M AND ROSA AO. 1997. Pesquisas arqueológicas em Santa Vitória do Palmar, RS. In: Schmitz PI. Arqueologia do Rio Grande do Sul, Brasil. Instituto Anchietano de Pesquisas-UNISINOS, São Leopoldo, Documentos 07, 95 p.

SEMPREBON GM AND RIVALS F. 2010. Trends in the paleodietary habits of fossil camels from the Tertiary and Quaternary of North America. Palaeogeogr Palaeocl Palaeoecol 295(1-2): 131-145.

SMALLEY IJ. 1966. The properties of glacial loess and the formation of loess deposits. J Sedim Petrol 36(3): 669-676.

SMALLEY IJ. 1971. "In situ" theories of loess formation and the significance of the calcium-carbonate content of loess. Earth-Sci Rev 7(2): 67-85.

SOIL SURVEY DIVISION STAFF. 1993. Soil survey manual. Soil Conservation Service. U.S. Department of Agriculture Handbook 18, 315 p.

SOLIANI JR E. 1973. Geologia da Região de Santa Vitória do Palmar, RS, e a Posição Estratigráfica dos Fósseis de Mamíferos Pleistocênicos. Programa de Pós-Graduação em Geociências, Universidade Federal do Rio Grande do Sul (UFRGS), MSc Dissertation, 88 p. (Unpublished).

STEVAUX RS AND DILLENBURG SR. 2011. Propriedades sedimentológicas e mineralógicas das barreiras costeiras do Rio Grande do Sul: uma análise preliminar. In: Congresso da Associação Brasileira de Estudos do Quaternário, 13, 2011. Búzios, Brasil. Resumos Expandidos, available at: www.abequa.org.br

STILES CA, MORA CI AND DRIESE SG. 2001. Pedogenic iron-manganese nodules in Vertisols: A new proxy for paleoprecipitation? Geology 29(10): 943-946.

STUTE M, FORSTER M, FRISCHKORN H, SEREJO A, CLARK JF, SCHLOSSER P, BROECKER WS AND BONANI G. 1995. Cooling of Tropical Brazil $\left(5^{\circ} \mathrm{C}\right)$ during the Last Glacial Maximum. Science 269: 379-383.
TERUGGI ME. 1957. The nature and origin of Argentine loess. J Sedim Petrol 27(3): 322-332.

TÓFALO OR AND MORRÁS HJM. 2009. Evidencias paleoclimaticas en duricostras, paleosuelos y sedimentitas silicoclasticas, del Cenozoico de Uruguay. Rev Asoc Geol Argentina 65(4): 674-686.

TOMAZELLI LJ AND DILLENBURG SR. 2007. Sedimentary facies and stratigraphy of a last interglacial coastal barrier in south Brazil. Mar Geol 244: 33-45.

TOMAZELLI LJ, DILLENBURG SR AND VILLWOCK JA. 2000. Late Quaternary geological history of Rio Grande do Sul coastal plain, southern Brazil. Rev Bras Geoci 30(3): 474-476.

TOMAZELLI LJ AND VILLWOCK JA. 2005. Mapeamento geológico de planícies costeiras: o exemplo da costa do Rio Grande do Sul. Gravel 3: 109-115.

TONNI EP, CIONE AL AND FIGINI AJ. 1999. Predominance of arid climates indicated by mammals in the pampas of Argentina during the Late Pleistocene and Holocene. Palaeogeogr Palaeocl Palaeoecol 147: 257-281.

TONNI EP, CIONE AL AND FIGINI AJ. 2001. Chronology of Holocene pedogenetic events in the Pampean area of Argentina. Curr Res Pleist 18: 124-127.

TONNI EP, HUARTE RA, CARBONARI JE AND FIGINI AJ. 2003. New radiocarbon chronology for the Guerrero Member of the Luján Formation (Buenos Aires, Argentina): paleoclimatic significance. Quatern Int 109110: 45-48.

TSOAR H AND PYE K. 1987. Dust transport and the question of desert loess formation. Sedimentology 34: 139-153.

UBILLA M, OLIVEIRA EV, RINDERKNECHT A AND PEREIRA JC. 2008. The hystricognath rodent Microcavia in the late Pleistocene of Brazil (Rio Grande do Sul, South America) (Mammalia: Caviidae). Biogeographic and paleoenvironmental implications. Neues Jb Geol P-Abh 247(1): 15-21.

UBILLA M AND RINDERKNECHT A. 2014. The plains vizcacha Lagostomus maximus (Desmarest) in the late Pleistocene of Uruguay: biogeographic and environmental considerations. In: International Paleontological Congress, 4, 2014, Mendoza, Argentina. Abstracts, p. 829.

UBILLA M, RINDERKNECHT A, PEREA D AND SÁNCHEZ A. 2011. Late Pleistocene-early Holocene mammals of the Santa Lucía basin (southern Uruguay). Ameghiniana 48(4) Supplement R131.

VELDE B. 1985. Clay Minerals - A Physico-Chemical Explanation of their Occurrence. Elsevier Science Publishers BV, Amsterdam, 427 p.

VELDE B AND MEUNIER A. 2008. The Origin of Clay Minerals in Soils and Weathered Rocks. Berlin, SpringerVerlag, $406 \mathrm{p}$.

VEPRASKAS MJ AND LINDBO DL. 2012. Redoximorphic features as related to soil hydrology and hydric soils. In: 
Lin H (Ed), Hydropedology - Synergistic Integration of Soil Science and Hydrology. Amsterdam, Academic Press, p. 143-172.

VEROSLAVSKY G, UBILLA M AND MARTÍNEZ S. 2004. Cuencas sedimentarias de Uruguay: Geología, paleontología y recursos naturales - Cenozoico. Montevideo, DIRAC, $448 \mathrm{p}$.

VILLWOCK JÁ AND TOMAZELLI LJ. 1995. Geologia Costeira do Rio Grande do Sul. Notas Téc 8: 1-45.

WENTWORTH CK. 1922. A Scale of Grade and Class Terms for Clastic Sediments. J Geol 30(5): 377-392.

WRIGHT JS. 2001. "Desert" loess versus "glacial” loess: quartz silt formation, source areas and sediment pathways in the formation of loess deposits. Geomorphology 36: 231-256.

YANN LT AND DESANTIS LRG. 2014. Effects of Pleistocene climates on local environments and dietary behavior of mammals in Florida. Palaeogeogr Palaeocl Palaeoecol 414: 370-381.

ZÁRATE M. 1991. Late Pleistocene and Holocene loess deposits of the southeastern Buenos Aires province, Argentina. Geojournal 24(2): 211-220.

ZÁRATE M. 2003. Loess of southern South America. Quaternary Sci Rev 22: 1987-2006.

ZÁRATE M. 2006. Loess Records / South America. In: Elias SA(Ed), Encyclopedia of Quaternary Science. Amsterdam, Elsevier Science, p. 1466-1479.
ZÁRATE M AND BLASI A. 1991. Late Pleistocene and Holocene Loess Deposits of the Southeastern Buenos Aires Province, Argentina. Geojournal 24(2): 211-220.

ZÁRATE M AND BLASI A. 1993. Late Pleistocene-early Holocene aeolian deposits of the southern Buenos Aires Province, Argentina: a preliminary model. Quatern Int 17: 15-20.

ZÁRATE M, KEMP R AND TOMS P. 2009. Late Quaternary landscape reconstruction and geochronology in the northern Pampas of Buenos Aires province, Argentina. J S Am Earth Sci 27: 88-99.

ZÁRATE M AND TRIPALDI A. 2012. The aeolian system of central Argentina. Aeolian Res 3: 401-417.

ZECH R, MAY J-H, KULL C, ILGNER J, KUBIK PW AND VEIT H. 2008. Timing of the late Quaternary glaciation in the Andes from $15^{\circ}$ to $40^{\circ} \mathrm{S}$. J Quat Sci 23: 635-647.

ZHANG Z, ZHAO M, LU H AND FAIIA AM. 2003. Lower temperature as the main cause of $\mathrm{C} 4$ plant declines during the glacial periods on the Chinese Loess Plateau. Earth Planet Sc Lett 214: 467-481.

ZINCK JA AND SAYAGO JM. 1999. Loess-paleosoil sequenceof La Mesada de Tucumán Province, northwestern Argentina: characterization and paleoenvironmental interpretation. J S Am Earth Sci 12: 293-310.

ZINCK JA AND SAYAGO JM. 2001. Climatic periodicity during the late Pleistocene from a loess-paleosoil sequence in northwest Argentina. Quatern Int 78: 11-16. 